

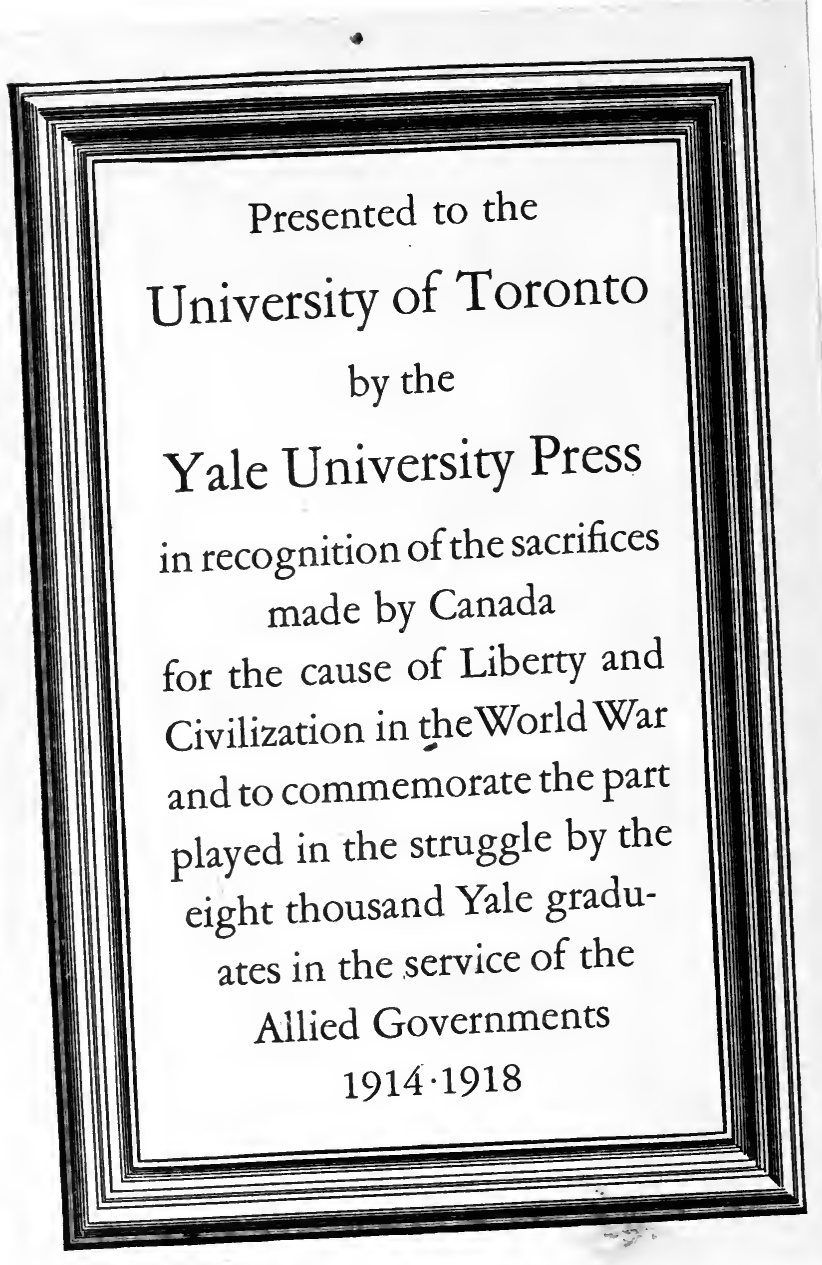





\section{Digitized by the Internet Archive in 2008 with funding from Microsoft Corporation}


YALE LECTURES ON THE RESPONSIBILITIES OF CITIZENSHIP

\section{THE CITIZEN'S PART IN G O V E R N M N T}




\section{YALE LECTURES ON THE RESPONSIBILITIES OF CITIZENSHIP}

American Citizenship. By the late David J. Brewer, Associate Justice of the Supreme Court of the United States. 131 pages.

The Citizen in His Relation to the Industrial Situation. By the late Henry Codman Potter, D.D., LL.D., Bishop of New York. 248 pages.

The Relations Between Freedom and Responsibility in the Evolution of Democratic Government. By Arthor Twining Hadley, Ph.D., LL.D., President of Yale University. (Third printing.) 175 pages.

Four Aspects of Civic Duty. By William Howard Taft, LL.D., D.C.L., as President of the United States. (Second printing.) 111 pages.

The Citizen's Part in Government. By Hon. Elihu Root, LL.D., D.C.L. (Second printing.) 123 pages.

The Hindrances to Good Citizenship. By RT. Hon. James Bryce, D.C.L., LL.D., F.R.S., British Ambassador to the United States. (Fourth printing.) 138 pages.

Conditions of Progress in Democratic Government. By Charles Evans Hughes, LL.D., formerly Associate Justice of the Supreme Court of the United States. (Second printing.) 123 pages.

America in the Making. By Rev. Lyman Abbott, D.D., LL.D., Editor of "The Outlook." 234 pages.

The Relations of Education to Citizenship. By Simeon E. BALDwin, LL.D., ex-Governor of Connecticut. 178 pages.

The Power of Ideals in American History. By Ephraim Dougras Adams, Ph.D., Professor of History, Leland Stanford Jr. University. 159 pages.

The Liberty of Crtizenship. By Hon. Samuel Walker McCALL, LL.D., ex-Governor of Massachusetts. (Second printing.) 134 pages.

The Constitution of Canada in rts History and Practical Working. By William Renwick Riddele, LL.D., Justice of the Supreme Court of Ontario. 170 pages.

Policeman and Public. By Arthur Woods, A.M., Colonel, Air Service, U. S. A., formerly Police Commissioner of New York City. 178 pages.

Uniform 12mo cloth bound volumes.

Society and Prisons. By Thomas Mott Osborne, L.H.D. (Fourth printing.) 8vo. Cloth binding. 246 pages. 


\title{
THE CITIZEN'S PART IN GOVERNMENT
}

\author{
BY \\ ELIHU ROOT
}

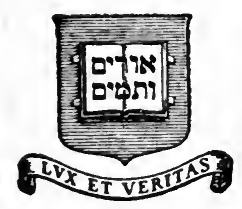

$\frac{166690 .}{3.11 .21 .}$

\author{
NEW HAVEN \\ YALE UNIVERSITY PRESS \\ LONDON : HUMPHREY MILFORD : OXFORD UNIVERSITY PRESS \\ MDCCCCXX
}


COPYRIGHT, 1907, BY

\section{YALE UNIVERSITY}

First published, 1907

Second printing, 1920 


\section{CON'TENTS}

PAGE

Prhatory Remarks . . . . . . . . . . 3

I. The TASK INHerited OR Assumed by MemBers OF THE GoverniNg BODY IN A Democracy . . . • . • . . . . 5

II. The Function of Political Parties as Agencies of the Governing Body . 32

III. The Dutiks of the Citizen as a MemBer of a Political Party . . • . 61

IV. The Grounds for Encouraghment . . . 93 


\section{THE}

\section{CITIZEN'S PART IN GOVERNMENT}




\section{PREFATORY REMARKS}

Gentlemen of Yale University:

In delivering the lectures of 1907 on the responsibilities of citizenship, upon the foundation established by the late William Earl Dodge, I look back with pleasure to nearly forty years of friendship with Mr. Dodge, and to the example which his whole life gave of unselfish public spirit and of unremitting and intelligent effort for the welfare of his country and of his fellow-men. The establishment of this lectureship is but one of a multitude of acts which expressed his constant solicitude for the welfare of others and his grateful appreciation of all the blessings he owed to the just and equal laws, the liberty, and the opportunities of his country. His life was a better lesson in the responsibility of Christian citizenship than any lecturer can put into words; for he did what we write about and he proved what we assert. 
It is my purpose to speak to you of your responsibilities regarding the government of your country and to discuss:

1. The task inherited or assumed by members of the governing body in a democracy.

2. The function of political parties as agencies of the governing body.

3. The duties of the citizen as a member of a political party.

4. The grounds for encouragement. 


\section{I}

THE TASK INHERITED OR ASSUMED BY MEMBERS OF THE GOVERNING BODY IN A

\section{DEMOCRACY}

A large part of mankind still regard government as something quite apart from the main business of life-something which is undoubtedly necessary to enable them to attend to their business, but only incidental or accessory to it. They plough and sow and harvest; they manufacture and buy and sell; they practise the professions and the arts; they write and preach; they work and they play, under a subconscious impression that government is something outside all this real business-a function to be performed by some one else with whom they have little or no concern, as the janitor of an apartment house, whom somebody or other has hired to keep out thieves and keep the furnace running. In reality, government is an essential part in every act of all this wide range of human activity. If it is bad, ruin comes to all; if it is good, success comes according to 


\section{THE CITIZEN'S PART IN GOVERNMENT}

capacity and courage. The fairest and most fertile parts of the earth have been for centuries wilderness and desert because of bad government; not only lands capable of supporting multitudes in comfort and prosperity, but lands that have actually done so in the past, are to-day filled with wretchedness and squalor, with ignorance and vice, because of bad government; while under good government industry and comfort flourish on the most sterile soil and under the most rigorous climate.

The proportional part played by government in the personal affairs of every individual life is rapidly increasing. The crowding and complications, the inventions and improvements and coöperation of modern life have enormously increased the dependence of men upon each other. A century ago the farmers, who made up the bulk of the people of the United States, were quite independent in their comparatively isolated lives and with their few wants. I can recall a picture drawn by one who remembered the life of that time upon a farm familiar to my childhood. He said:

We had abundance of food and clothing; we raised our own wheat and corn, which were ground into flour 
and meal at a neighboring mill for a share of the grain; we raised all the beef and pork and vegetables that we required; we raised sheep and sheared them, and carded and spun and wove the cloth for our winter clothing; we raised flax and from it made our own linen; we dipped our own candles, which afforded sufficient artificial light for a life in which it was the rule to rise with daylight and go to bed when it was dark; we had milk from our own cows, eggs from our own fowls, and abundant firewood from our own forest. We had everything we needed except money and we had little need for that; the chief occasion for its use was to pay the small taxes which were required each year. There was little money in the community and it was sometimes hard to get enough to meet the taxes.

Under such conditions, government might well have been regarded as an outside affair, of which the less people heard the better.

Compare such a life with that of a resident in one of the cities, in which a third of the population of the United States are now crowded together. The city family is dependent for every article of food and clothing upon the products of far-distant places. These products are supplied through great and complicated agencies of trans portation, and for the most part have been pre- 


\section{THE CITIZEN'S PART IN GOVERNMENT}

pared for use by a variety of distant mills and factories. The family depends upon fuel brought from distant coal-mines; its light comes from gas and electrical plants over which it has no control; the habits of business and social life are all adjusted to means of communication furnished by great telegraph and telephone companies and a government postal service. It exercises no control at all over the things that are absolutely necessary to its daily life. A strike in the coal-mines, like that which occurred in Pennsylvania five years ago, may at any time put out not only the furnace but the kitchen fire; a strike in the lighting plants, like that which happened in Paris a few weeks ago, may plunge the house and the neighborhood into darkness. A quarrel between railroad companies and their employees, or the inability of a railroad company to furnish sufficient transportation, may cut off the most necessary supplies; the meat is liable to be diseased unless some one inspects the packing-house, the name and place of which no one in the family knows. The milk may be full of tuberculosis and the water full of typhoid germs unless some one has tested the cattle and some one enforced sanitary ordinances upon 
distant farms. Access to the house depends upon a street department, safety from thieves upon a. police force, and freedom from pestilence upon the sanitary disposal of the sewage of thousands of other families. Under these circumstances of complete interdependence, the individual is entirely helpless. The only way in which he can compel the continuance of conditions under which he and his family can go on living is by combination with others equally dependent with himself, and by organization for whatever control over those conditions is necessary. That combination and organization is government.

Men may leave all this part of the business of life to others and treat it as no concern of theirs; men may voluntarily elect to play no part in the control of the affairs which make up their daily life and to play no part in the working out of the great questions upon which the prosperity of their country, the future of their children, and the welfare of the race depend; but they need not flatter themselves that these things are matters apart from them, or that they are leading free and independent lives. Abstention is impossible under the conditions of modern life and modern popular 


\section{THE CITIZEN'S PART IN GOVERNMENT}

government. Men must either govern or be governed; they must take part in the control of their own lives, or they must lead subject lives, helplessly dependent in the little things and great things of life upon the will and power of others.

The theory and practice of government have vastly changed within the past few centuries, and especially within the last century and a half. Control by superior authority, claiming by divine right, selected by inheritance, and supported by a comparatively small governing class selected in the same way was repressive and directive. Government was then apart from the main and general activities of life, but it was apart from them by being above them, by exercising rights over them and making them all pay tribute. Under our modern systems of popular government the repressive function still continues, but entirely new and different modes of action have been developed. The repression is self-repression, and the direction is the resultant of internal forces determining the character of the directed mass. Popular government is organized self-control-organized capacity for the development of the race. It is the good and noble impulses and the selfish 
and cruel passions of man struggling with each other for the maintenance or the denial of justice; it is the lust for power and savage instinct for oppression struggling against manhood and selfrespect for the maintenance or destruction of liberty; it is the greed and cunning that have shamed the history of the world struggling with honesty and virtue for public purity; it is the longing in the heart of man for better things up through education to broader knowledge and higher life; it is the vast elemental forces of humanity moving great masses of men in violent protest against the ills of life, to the destruction of social order; it is the instinct of self-preservation which rallies other multitudes in defence of vested interests and traditional rights; it is the dreams of Utopia to be realized by changing everything and the reverence for the past that is horrified by changing anything. These tremendous forces express themselves in laws, in the enforcement of laws, in contempt for laws, in good administration and bad administration, in sudden outbursts of feeling altering the surface of things, and in gradual movements affecting the whole relation of nations toward the ideals of peace and order and justice 
and righteousness. Upon them and the results they work out depend the prosperity and honor and life of nations, and the future of civilization; and upon them depend the value of every farm and factory and shop, of every bond and share of stock, the peaceful prosperity of every home, the opportunities for success of every child.

Heavy responsibilities were assumed and serious dangers were confronted in departing from the theory that government must come from above, that the selfishness and cruelty and lust of mankind can be successfully controlled only by a class of superior men, by a small number of specially qualified experts in the art of government bred to power and trained in its exercise; and in adopting the idea that the great masses of men, who had always been subject to repression, control, and direction, could be trusted to govern themselves without any superior control; that by a process of evolution, through education and practice, the popular mass would acquire the self-restraint, the soberness of judgment, the loyalty to the fundamental principles of justice and liberty necessary to stable and effective government. The new departure was regarded by many of the wisest and 
best of mankind with the most gloomy forebodings. There was widespread belief that when political power was vested in the poor they would promptly proceed to divide among themselves the property of the rich, and that the control of democracy would prove to be the tyranny of the mob-the most frightful form of oppression mankind has yet known. Jack Cade and Wat Tyler rebellions, peasant insurrections, the Red Terror of the French Revolution, the excesses of the Commune of Paris, the reign of assassination in Russia, the Jacquerie in Roumania, the perpetual revolutions of undeveloped Latin-America, have seemed to give color to these anticipations.

We have been accustomed to flatter ourselves that the great American experiment has been successful. It has indeed carried the demonstration of popular capacity of the people to rule themselves far beyond the point which originally seemed possible to the enemies of popular government. That demonstration has produced an effect upon the constitution of government throughout the civilized world by the side of which the Roman dominion sinks to an inferior place as a permanent force. Under its influence the whole continent of 


\section{THE CITIZEN'S PART IN GOVERNMENT}

South America took heart and gathered courage to throw off the hard colonial yoke which held its people under the subjection of the Iberian Peninsula, and, passing through the storms of internal strife and continual revolution, is gradually emerging into a condition of peaceful industrialism. Its influence reacted upon France and requited her assistance in the cause of our independence, by furnishing proof of the possibilities of humanity to her political philosophers. It inspired the hope that led to the tempestuous revolt against the French Monarchy, which, through many vicissitudes, has resulted in the French Republic, now for more than a third of a century stable in its peaceful sway. Its example reacted upon England in the series of reforms which began with the Reform Bill of 1832 and enabled that conservative people to impress upon their ancient Monarchy the essentials of a real government by the people, in which justice and liberty are preserved in a very high degree.

The fact that for more than a century peaceful industry, respect for law, and individual freedom have been maintained under popular government in the United States, and that they have been 
accompanied by extraordinary material prosperity, has fostered a tendency toward popular government in every country of Europe.

Nevertheless, we must not delude ourselves with the idea that the American experiment in government is ended or that our task is accomplished. Our political system has proved successful under simple conditions. It still remains to be seen how it will stand the strain of the vast complication of life upon which we are now entering.

Notwithstanding the change in the source of power, which has been the fundamental fact in the development of popular government, that government has proceeded hitherto with much respect for inherited governmental traditions and methods. The old machinery for the application of governmental power to the life of the community has been in a great measure preserved. Legislative bodies have made laws, and courts have sat in judgment under them and executives have enforced them, under authority derived from the people, very much as they did under authority derived from a superior power, except that the spirit has been different and the responsibility has been different. It remains to be seen whether 
democracies will be willing to continue these methods of government, or whether, with their continually increasing realization of their own power, they will change the old methods of government along such lines as are foreshadowed by the proposals for the initiative and the referendumproposals that would substitute direct democratic action for representative government, as representative government was substituted for absolute monarchical control; and it remains to be seen what the effect of that kind of government would be.

Notwithstanding the great change at the top involved in the setting aside of monarchical and aristocratic government in modern republics, the substance of the old social system, with its respect for the rights of private property, has been preserved. Modern democracy has simply engrafted upon that system an assertion of the right of equal individual opportunity, so that no barrier of birth or caste or privilege shall stand between any man and whatever career his ability and industry and courage entitle him to achieve. The very basis of that social system is now widely questioned. Socialists, in no negligible numbers, demand a reorganization of society upon entirely different 
principles; limitations upon the right of private property are widely favored; and limitations upon individual opportunity are still more widely enforced among all that part of the wage workers who believe in putting a limit upon the amount of work which each workman shall be permitted to do in his day's labor, so that the most industrious, skilful, and ambitious workman shall be permitted to do no more and to earn no more than the most dull, idle, and indifferent workman. A common benefit of property and a common standard of exertion are liable to be substituted for all inequalities of fortune and achievement. After many centuries of struggle for the right of equality there is some reason to think that mankind is now entering upon a struggle for the right of inequality. It remains to be seen how democracy will work under these new conditions.

One thing we have learned during the experience of popular government is that the progress of the world has carried civilized people to a point where we are not now voluntarily trying the experiment of government by self-control, but where society must rely upon that and cannot possibly go back to the old method of keeping peace by 


\section{THE CITIZEN'S PART IN GOVERNMENT}

force or the threat of force. The complication and interdependence of life puts the power of doing incalculable harm in the hands of so many men and combinations of men in different occupations that a realization of common interest is absolutely essential to the working of the vast machine. The mere forcible enforcement of law is quite inadequate. It is not fear of the policeman or the sheriff that keeps the peace in our many cities; it is the self-control of the millions of inhabitants enabling them to conform their lives to the rules of conduct necessary to the common interest; it is only against the exceptional lawbreaker, and criminals who are comparatively few in number, that the policeman and sheriff are effective.

Another thing we have learned is that it is possible for men to set up abstract and impersonal standards of right conduct, such as the great rules of right embodied in our constitutions, and that, although each man in his own personal affairs tends to depart from the standard and struggle against its application to himself, the general agreement of all who do not at the time happen to have any adverse interest is competent to maintain the standard in force and effect; so that all men 
may give their adherence and support to standards of conduct ethically superior to the course which the vast majority of them desire to take in their own affairs.

Another lesson the experience of popular government has already made plain is that the art of self-government does not come to men by nature. It has to be learned; facility in it has to be acquired by practice. The process is long and laborious; for it is not merely a matter of intellectual appreciation, but chiefly of development of character. At the base of all popular government lies individual self-control; and that requires both intelligence, so that the true relation of things may be perceived, and also the moral qualities which make possible patience, kindly consideration for others, a willingness to do justice, a sense of honorable obligation, and capacity for loyalty to certain ideals. Men must be willing to sacrifice something of their own apparent individual interests for the larger interests of city, State, country; and without that willingness successful popular government is impossible. This loyalty to an abstract conception is a matter of growth. It is easy to trace its development in our own country 


\section{THE CITIZEN'S PART IN GOVERNMENT}

from the time when local allegiance was predominant to the time when national allegiance has become predominant. Intense devotion to the State is one of the great elements of strength in the Japanese nation now ; it was one of the chief elements in the growth of Roman power. It cannot be produced except by a long-continued habit of effort and sacrifice in a common interest. It is this gradually acquired loyalty to country more than anything else that enables men to exercise the self-control necessary to the subordination of the narrower personal interests to broader general interests, upon which self-government depends. The individual selfishness which fills men with a controlling desire for personal aggrandizement, to the exclusion of any consideration for the general good, marks a low stage in the political development of every country that has a history; and the bitterness of internal dissension which leads the adherents of particular opinions or interests to insist upon them at the cost of ruin and death to adherents of opposing views in the same country must in its turn give way to the conception of the higher loyalty before there can be really successful popular government. There must be both the 
habit of self-control and the dominating influence of the common ideal to enable men so to act together, subordinating minor differences of interest and opinion, as to make popular government possible.

The countries in which the people are continually engaged in internal quarrels never progress. History is full of such examples. Some races appear to be incapable of combining in the support of a common political ideal beyond a certain point. The races that have this capacity to the highest degree persist and rule the world; the peoples that have it to a low degree lose their national entity and cease to govern. There are many countries now where controversy regarding matters of inferior importance is a present bar to progress. In every living nation the question always remains, How far has it capacity to go in that kind of combined action which subordinates individual interests, the interests of groups and localities and classes, to the general good of the country? That limit must be found in the capacity for development of the individual characters that make up the nation. The Greeks appeared to be unable to maintain any effective combination beyond the individual city; the idea of a Hellenic country 


\section{THE CITIZEN'S PART IN GOVERNMENT}

acquired no control over their lives. When the supreme moments were passed in which they united to repel the Persian invasions, they immediately fell apart and resumed their quarrelling with each other. The Peloponnesian and Delian Confederacies, which might as well have been the foundations of a common country as the Confederation of the American colonies, served merely as opportunities for the selfish advantage of Sparta and of Athens. So Greece, with all its glories of art and literature and oratory, went down before nations of inferior intellectual capacity-first the Macedonians and then the Romans. The long period during which internal strife has prevailed in the Latin-American countries has been an illustration of the struggle between the capacity for self-control in a common national interest and the forces of selfish individualism and factionalism. The major part of those countries are now happily emerging from the stage of militarism and the condition of continual revolution into the stage of industrialism and stable government; but in some of them on the borders of the Caribbean the struggle is still waged and the result is in doubt. The discord between the thirteen American States and 
the practical paralysis of the Continental Government before the Constitution of 1787 illustrates the failure to attain this necessary condition; and the union of the same States under the Constitution illustrates success. The downfall of the once powerful Kingdom of Poland illustrates the triumph of those discordant motives which make successful government impossible. United Italy and Germany; the stability which the French Republic has maintained for a third of a century after so long a period of tumult and discord; the unbroken bonds that unite Great Britain with her colonies; and the permanence of the American Union, mark the great advances of which civilized men generally have proved themselves capable, in applying the principles of combination for a common national interest. No one can tell, however, when or where the great new forces which are being developed in the course of government by the people, and especially in the relations between industrial and social changes and the political constitution of government, will overcome the power of common and patriotic purpose that makes possible combined national action.

Our country is not safe.in leaving unused any 


\section{THE CITIZEN'S PART IN GOVERNMENT}

possible influence and effort toward the maintenance and growth of patriotic idealism and practical loyalty.

There are probably few readers of history who do not ask themselves the question whether the civilization of our time is to pass through its cycle of development and decay, yield to the disintegrating passions of human nature, and leave the world to begin the process again as it has so often done. Is the New Zealander indeed to stand on the ruins of London Bridge? The question that Macaulay asks still remains to be answered:

Is it possible that in the bosom of civilization itself may be engendered the malady which shall destroy it? Is it possible that institutions may be established which, without the help of earthquake, of famine, of pestilence, or of the foreign sword, may undo the work of so many ages of wisdom and glory, and gradually sweep away taste, literature, science, commerce, manufactures, everything but the rude arts necessary to the support of animal life? Is it possible that, in two or three hundred years, a few lean and half-naked fishermen may divide with owls and foxes the ruins of the greatest European cities-may wash their nets amidst the relics of her gigantic docks, and build their huts out of the capitals of her stately cathedrals? 
Is some future poet to sing of us that "the lion and the lizard keep the courts where Jamshyd gloried and drank deep"? If not, I think the difference must be found in the fact that popular government carries our civilization down to the foundations of society and spreads it so widely over the surface of the earth. Former civilizations were but islands surrounded by vast regions where savagery ruled; and they were but civilizations at the top, underlaid by the ignorance and prejudice of a multitude who had no interest in preserving what such civilization had gained, no capacity to appreciate its merits, and but little contribution to make toward its increase. They were the civilizations of privileged classes, which always tend toward degeneration. The hope for the permanence of modern civilization is that it is being built up from the bottom through the participation of the whole people in that universal, combined action for the common good which we call popular government.

It may seem that I have ascribed a part to government which properly belongs to the development of morals and the spread of education; but I think a little reflection will show that this is 


\section{THE CITIZEN'S PART IN GOVERNMENT}

not so. Morals do not develop in the abstract, but in the gradual adaptation of conduct to rules already intellectually accepted. The conduct to be adapted is conduct toward other real living beings. Even in the purely personal relations government plays a leading part in directing conduct, as in the changing rules of law regarding the rights and duties of owner and slave, master and servant, employer and laborer, parent and child, guardian and ward; but in the great field of the relations of men to each other in the mass the whole development of morals practically is governmental. The words liberty, justice, order, peace, protection of the weak, public purity, public spirit, denote the application of certain moral ideas to the conduct of men in mass toward their fellow-men. The tremendous power of a people become sovereign and the helpless dependence of modern men upon each other make this phase of development of morals of primary and vital importance. It is the conversion of moral rules into political conduct that concerns government, and that is a process of practical experimental life working out results acceptable to a majority and then enforced by them upon the minority. This process is not 
much furthered by mere insistence upon the rules, or by academic discussion of them, for in successive generations the same accepted moral rules are translated into entirely different conduct, and it is the translation which is of vital importance.

If we turn to education, we find that instead of this being a thing apart, the education which enables the great body of democracy to work out the problems I have described-the primary education, which opens the door of knowledge to the mass and the door of unlimited opportunity to the exceptional intelligence-is almost universally supplied by government as a part of the political qualification for citizenship. On the other hand, it is very doubtful whether the higher academic education contributes much to capacity for political usefulness. As a rule, political wisdom, in the best sense, comes in life and not in study, and the tendency of highly educated men to neglect all political duties is unfortunately too general. It is the process of government that educates for government. It is experience and observation of the working of laws and political practices and injurious customs that point the way to intelligent legislation. The factory inspectors in the State of 


\section{THE CITIZEN'S PART IN GOVERNMENT}

New York inspected over thirty-eight thousand separate factories last year. Those inspections and the reports and the discussions on them are education through which the thirty-eight thousand employers and the million and odd employees and the community which controls them both, may come to a sense of just how the balance ought to be held between the employer's rights of property and free contract, on one hand, and the employee's freedom from the slavery of circumstance, and the State's right to have normal, healthy citizens, on the other.

The greatest, most useful educational process ever known in the world occurs every four years in the United States when, during a Presidential election, some fifteen million voters are engaged for months in reading and hearing about great and difficult questions of government, in studying them, in considering, and discussing, and forming matured opinions about them. We sometimes hear complaints that elections interfere with business and come too frequently. On the contrary, nothing else is so valuable and important for business, because it is this educational process that is laying the solid foundation of sound judgment, sober 
self-restraint, and familiarity with political questions among the governing mass, upon which the security of all business depends.

Doubtless there have been abuses in raising and applying campaign funds; but, in the main, there is no more useful expenditure of money from the public point of view than this, which in the last Presidential election, according to official statements, amounted to only about three and a half cents per capita for the people of the United States, on one side, and probably somewhat less on the other; for the great bulk of it is applied to the political education of voters.

Everything that I have said about the relations of government to our modern life-the character of popular government, its difficulties, its dangers, its possibilities, its mode of life and growth-carries, as a necessary corollary, the existence of a universal duty of citizenship to take part in it. It is not rightly a matter of choice whether a man shall trouble himself about affairs of government in his community, or confine himself to his business, his profession, or his pleasures, and leave others to govern; it is a matter of peremptory obligation which cannot be avoided by any intelli- 


\section{THE CITIZEN'S PART IN GOVERNMENT}

gent man who has any understanding of the conditions under which he lives. A French nobleman could attend the Court of Louis XIV, or retire to his castle, as he chose, without discredit; for under that system of government the question was whether certain men or certain other men conducted the government. The essential feature of the present condition is that the burden and duty of government rest upon all men, and no man can retire to his business or his pleasures and ignore his right to share in government without shirking a duty. The experiment of popular government cannot be successful unless the citizens of a country generally take part in the government. There is no man free from the responsibility; that responsibility is exactly proportioned to each man's capacity - to his education, to his experience in life, to his disinterestedness, to his capacity for leadership-in brief, to his equipment for effective action in the great struggle that is continually going on to determine the preponderance of good and bad forces in government, and upon the issue of which depend results so momentous to himself, his family, his children, his country, and mankind. The selfish men who have special interests 
to subserve are going to take part; the bitter and malevolent and prejudiced men whose hearts are filled with hatred are going to take part; the corrupt men who want to make something out of government are going to take part; the demagogues who wish to attain place and power through pandering to the prejudices of their fellows are going to take part. The forces of unselfishness, of selfcontrol, of justice, of public spirit, public honesty, love of country, are set over against them; and those forces need every possible contribution of personality and power among men, or they will go down in the irrepressible conflict. The scheme of popular government upon which so much depends cannot be worked successfully unless the great body of such men as are now in this room do their share; and no one of us can fail to do his share without forfeiting something of his title to selfrespect. 


\section{II}

THE FUNCTION OF POLITICAL PARTIES AS AGENCIES OF THE GOVERNING BODY

We have now reached a point where the question is naturally suggested: How should the citizen take part in the government of his country? Given a young American who has just completed his academic training and is about to begin his active life, and who wishes to do his full duty as a citizen in maintaining and improving his Government: where is he to begin and what is he to do?

On the threshold of the answer to this question we must determine that the duty will not be fulfilled merely by playing the rôle of a critical observer of what others do. It is indeed important that there should be criticism; no public officer can afford to be relieved from it. Every man in the performance of public duty tends to lose his sense of proportion by seeing things from only one 
point of view, and tends to devote himself unduly to some phases of his work, which preoccupy his mind, so that he neglects other things which ought to have his attention. Every one makes mistakes, and the sooner he is told of them the better; and every one who is obliged to withstand the pressure which conflicting interests bring to bear upon the performance of his duty finds in the certainty of criticism a powerful incentive to be sure that his action is such that he can defend it afterward according to his own convictions of right. Criticism tests and corrects the opinions and the practices of the men who are doing the work of the world.

Nevertheless, to criticise is not to do the work. The preservation and development of civilization require affirmative forces; the real work of life is constructive; criticism is destructive.

It is, moreover, true that the most valuable criticism comes from the men who are also undertaking to do things themselves. Criticism always involves comparison with some standard assumed in the critic's mind; and the value of the criticism depends largely on the conformity of that standard to the real conditions under which the work 


\section{THE CITIZEN'S PART IN GOVERNMENT}

criticised is done. The critic of government who is himself trying to do his share of the affirmative work of government is in the way of learning something of the evils against which other men engaged in government are struggling, the difficulties they have to overcome, the means they have at their command with which to overcome those difficulties, and the real as distinguished from the apparent value of what they do. Criticism from such a source is a real benefit. The mere critic of government, however, who does not himself attend to his share in the affirmative work of government, ordinarily adopts standards of comparison which ignore the most important elements of truth, and he is quite likely to do more harm than good; he gradually assumes an attitude purely destructive and acquires a habit of simple faultfinding. Such a man is generally a hindrance rather than a help to the work of good government.

It is equally plain that for most men preaching to others about what they ought to do is not a very effective way of helping along the work of government. Mankind does not pay much attention to people who talk down at them from without about their duties, unless the instruction comes from 
some one who is already recognized by his own performance as having acquired the right to be considered a teacher. Occasionally a man has some message to deliver of such weight and cogency as to impress itself upon many other minds; but such men are very rare and very far removed from the ordinary run of men. If any one can express as much wisdom as President Eliot has put into some of his addresses, or can write such a book as President Hadley's "Freedom and Responsibility," or such a book as James Bryce's "American Commonwealth,”, or John Morley's “Life of Gladstone," or can compose such orations as Edmund Burke's, he can make a real contribution to the science, and therefore to the practice, of government. But for the generality of us whose knowledge and insight are not much, if any, superior to those of the great body of our fellows, it is wise to wait until we have at least greater experience than they have in the things we undertake to talk about, before we try to play the schoolmaster to them.

There are many people whose idea of duty is to assign duties to others, but for the most part their efforts are a mere waste of words. Mr. Murat Halstead once told me how, being a young news- 


\section{THE CITIZEN'S PART IN GOVERNMENT}

paper correspondent during the civil war, he had felt moved to write a long letter to Secretary Stanton, giving his view about the matters in which the Secretary was engaged, and how, many years afterward, this letter was found on the files of the War Department indorsed, in Stanton's own handwriting, "M. Halstead-Tells how the war ought to be carried on." At the time of our conversation, a long and ripe experience had taught the veteran journalist the true character of his youthful undertaking; and he remarked that this indorsement was the only evidence he had ever known that Stanton possessed real humor. The world is full of men ready to tell how the war ought to be carried on by others; but the war goes on just the same, and the men who bear the burden and heat of the struggle in actual service accomplish the results, and their self-constituted and little-qualified advisers have really no substantial part in the business.

It is plain that the true way to begin an active part in the affairs of government is not by being elected or appointed to office; that should always be a result rather than a beginning of interest, activity, experience, and proved capacity in the 
affairs of government. This is especially true of the greater offices. As to the smaller offices, especially those which occupy the entire time of the officer, it is often very undesirable for a young man of education and good parts to abandon his profession or business or whatever calling he would naturally follow to fill one of them. There are very few public offices in comparison with the number of citizens, and at the best only a very small part of the young men of the country could enter into active governmental work by holding them.

Of course, voting is a fundamental and essential part of the qualified citizen's duty to the government of his country. The man who does not think it worth while to exercise his right to vote for public officers, and on such public questions as are submitted to the voters, is strangely ignorant of the real basis of all the prosperity that he has or hopes for and of the real duty which rests upon him as a matter of elementary morals; while the man who will not take the trouble to vote is a poor-spirited fellow, willing to live on the labors of others and to shirk the honorable obligation to do his share in return. 


\section{THE CITIZEN'S PART IN GOVERNMENT}

Merely voting, however, is a very small part of the political activity necessary to popular government. An election is only the final step of a long process by which the character of government is determined. The election records the result of the process; the real work of government is in the process.

The voter ordinarily has merely a choice between two or three candidates for an office, no one of whom may be the man whom he would prefer for the office; or he has the opportunity to say yes or no to some question framed in advance, and very likely framed in such a way that neither yes nor no would represent his real opinion upon the subject or lead to what he would regard as a satisfactory result. Of course our election laws preserve the theoretical right of each voter to cast his vote for any one whom he chooses; but we all know that if the voter exercises that right for some one other than a foreordained candidate his ballot goes into the category of scattering votes and is practically thrown away. The same thing which is true as to the limitation of the voter to particular candidates is true also of the issues or opinions those candidates are supposed to repre- 
sent. The issues are all made up before the voter goes to the polls. You and I may feel a desire to express an opinion by our ballots on the revision of the tariff, or on free trade and protection, or on the regulation of railroads, or on the prevention of trusts, or on the method of taxation, or on economy and honesty of administration, or on the currency and banking system, or on the control of insurance companies, or on the powers of corporations, or on the open shop, or on the foreign policy of the country; but when we go to the polls merely as voters we are entirely helpless as to determining upon what question our votes will count, and ordinarily as to which way they will count upon many of the questions in which we are interested. The questions on one side or the other of which our votes will weigh, have all been selected and brought into prominence long before the election. The result of this is to limit the effect of our votes to certain narrow channels. The issues as finally framed may not be those we think most important, and the relation of the candidates to them may be such that we cannot help one cause by our vote without hurting another in which we are equally interested. The men who are elected to office give 
practical effect when in office to the results of that previous process recorded in the canvass of votes. Thus, the chief work of popular government is to be found in the process which results in the vote.

Under our present political system in the United States and at our present stage of political development, that process is mainly carried on through the organizations known as political parties.

Manifestly, there must be organization; there must be some means by which the vast number of questions which arise in relation to government in our complicated modern life shall be simplified; by which the questions that are vital shall be separated from the comparatively unimportant questions and the people who tend to think alike upon the vital questions may have an opportunity to make their votes effective by voting alike; by which, from the vast number of men who are available for selection to administer the powers of government, some may be indicated as the probable choice of a sufficient number of voters to give some chance of success in voting for them.

If you can imagine all the sixteen hundred thousand voters of the State of New York, for 
example, going to the polls on an election day with no previous concert of action, but each determined to vote for the best man-that is, each determined to vote for the man who of all his acquaintance seems to him the best to fill the position, or for the man whose opinion most closely agrees with his upon some subject which happens to be uppermost in his mind-what would be the result! what thousands of names would be found upon the ballots when they came to be counted! If a majority of votes were required to elect, of course there would never be an election. If only a plurality of votes were necessary to elect, the largest number of votes cast for any one man would inevitably be a very small proportion of the total of votes cast. It is highly probable that the great majority of the voters would have preferred that the man with the plurality should not be elected, and would have been quite ready to agree on some one else whom they all preferred to him and considered but little less desirable than the various persons for whom they had cast their scattering ballots. The men elected in such a way would have no guide as to the principles, or policies, or rules of conduct which the majority of the voters wished them 
to follow in the offices to which they were elected.

Such a method of conducting popular government, however, is not merely futile, it is impossible; for human nature is such that long before such an election could be reached some men who wished for the offices would have taken steps to secure in advance the support of voters; some men who had business or property interests which they desired to have protected or promoted through the operation of government would have taken steps to secure support for candidates in their interest; and some men who were anxious to advance principles or policies that they considered to be for the good of the commonwealth would have taken steps to secure support for candidates represẹnting those principles and policies. All of these would have got their friends and supporters to help them, and in each group a temporary organization would have grown up for effective work in securing support. Under these circumstances, when the votes came to be cast, the candidates of some of these extempore organizations would inevitably have a plurality of votes, and the great mass of voters who did not follow any organized leadership would 
find that their ballots were practically thrown away by reason of being scattered about among a great number of candidates instead of being concentrated so as to be effective.

Under very simple social conditions, especially in the smaller governmental subdivisions such as towns and counties, and in some parts of the country where there are few important questions involved in the local government and almost every one in the community is well known, so that elections are largely a matter of personal choice, this kind of purely personal organization and effort often answers the purpose of enabling voters to concentrate their ballots effectively. Several wellknown men may offer themselves publicly as candidates and each of them carry on, through a personal organization, a campaign for the suffrages of his fellow-citizens. In the governmental affairs of the country at large, however, and for the most part in the governmental affairs of the States, the opportunity for personal choice is very limited; it is impossible that any man should be really personally known to a very large proportion of the people in the United States, or even in any State. There are questions of government upon one side 


\section{THE CITIZEN'S PART IN GOVERNMENT}

or the other of which the voters hold strong opinions; and men are known and are commended to the voters as candidates by the positions they have taken upon those questions, and, if they have already held office, by public report of the way in which they have performed their duties in carrying out certain policies or applying certain rules of conduct. Candidates, therefore, in these larger fields are regarded chiefly as the representatives of principles and policies, and so far as they are affected by personal popularity; that is chiefly based upon the effectiveness with which they have already represented those principles and policies.

These great governmental questions are not temporary and special to particular elections. There are some questions of policy which are never settled permanently, because new conditions are always arising to serve as occasions for their reconsideration. For example, the subject of a protective tariff has furnished questions upon which the people of the United States have divided for a century, and probably will divide for an indefinite time to come. These tariff questions reappear in one form or another at every national election when they do not happen to be for the moment 
thrust aside by some other special and absorbing issue. The fact that the people have decided in favor of a high tariff at one time, or for a low tariff at another time, has no effect whatever to prevent the same old battle being fought over and over again.

Series of questions relating to the extension of slavery, merging into the questions relating to the continuance of the war for the Union, and these merging again into the questions relating to the results of the war and the political and economic status of former slaves, have continued from the beginning of the nineteenth century to the beginning of the twentieth. In the same way a long dividing line may be seen separating people of different ways of thinking upon questions relating to the currency. In one form or another, for a long series of years, the controversy has been waged between the advocates of currency based upon a gold value, on the one hand, and the advocates of a currency based upon the idea that the Government can give it value in the form of greenbacks or depreciated silver, on the other.

There are certain distinct and fundamentally opposed schools of thought and opinion which range 
portions of the people on different sides of many questions through long series of years. For example, the people of the United States during most of our national existence have been divided between the advocates of a strict construction and the advocates of a liberal construction of the Constitution. One would confine the powers of the National Government within the narrowest possible limits; the other would find in the Constitution all the powers that any nation can have except as they are expressly limited by the terms of the Constitution. One tends to carry the independence of local self-government to an extreme; the other tends to carry the centralization of national government to an extreme. This fundamental difference of view has divided the people of the country in a long series of successive elections upon many specific and important questions; upon the power of the National Government to carry on internal improvements; to restrict the extension of slavery; to establish a national bank; to charter Pacific railroads; to maintain a tariff for protection as distinguished from a tariff for revenue only; to acquire and incorporate in the United States additional territory; to acquire and 
govern so-called colonial possessions; upon the extent of the power to regulate commerce, of the taxing power, of the police power, of the treatymaking power.

It is true that in recent years some professed disciples of Jefferson have advocated measures of national control which would have led that apostle of the least government possible to regard Hamilton as a strict constructionist; but these are probably temporary aberrations. The same division between the two schools of interpretation of the Constitution still exists and in the nature of things must continue.

With these continuing questions and permanently divided schools of opinion the association of the advocates of each opposing view is bound to be repeated in many successive political campaigns. This association is not occasional and fortuitous; it is, to a great extent, predetermined and customary. The men who entertain positive views upon one side or the other of the great political questions become known; they acquire the habit of working together; they rely upon each other's cooperation. The association is practically continuous, because the process in which the advocates of 


\section{THE CITIZEN'S PART IN GOVERNMENT}

these differing views are engaged is continuous. Our people are so constituted that no sooner is an election over and the result declared than the supporters of the defeated candidates and the advocates of the rejected views immediately begin their efforts to secure a reversal of the result at the next election. The ever-present consciousness that in a year, or two years, or four years there will be an opportunity to substitute victory for defeat is a great element in the peaceable and good-natured acceptance of the results of our elections by those who are defeated. The very intensity of the minority's belief that its candidates and its policies are better than those which for the time being have a majority of the votes creates an expectation that when the test of performance is applied to the successful candidates and the test of application is applied to the accepted policies their inferiority will be demonstrated, so that the public verdict will be reversed.

This continuous association and effort on the part of a great number of men for the accomplishment of a common purpose through a continuous series of political struggles of course involves continuous organization, for the work of a great num- 
ber of men for a common purpose through a long period of time cannot be carried on at all without organization. These continuous, voluntary organized associations to secure the adoption of policies upon which their members agree and the choice of officers who will represent those policies are what we call political parties.

As new issues arise under the changing needs and difficulties and desires which time brings to every community they find these organizations already in existence, and if the new issues are such as to demand settlement or excite great interest among the voters it becomes immediately necessary for the existing political organizations to determine what positions they will assume upon the new questions. This determination is naturally based either upon the application of the general principles of government and the general ideas of policy which have controlled the respective parties, or upon an estimate of the support which one position or another will receive from the voters of the country, or upon a combination of the two. Sometimes the lines which separate the voters of the country upon one side or the other of a new question run across lines of cleavage between the 


\section{THE CITIZEN'S PART IN GOVERNMENT}

old parties, and the comparative importance of the new question is such that great bodies of voters dissolve their association with an old party and form a new association with another party; as, for example, the positions taken by the Democratic and Republican parties on the subject of the currency a few years ago led many gold Democrats to go over to the Republican party and many freesilver Republicans to go over to the Democratic party. Occasionally, the attitude of all existing parties is so unsatisfactory to the people much interested in a new question that they undertake to form a new party for the furtherance of their views on that particular question. Generally, these attempts show that the people who are interested by a particular new issue overestimate its importance and their attempts to form a new party fail; but we have had one signal example the other way-in the formation of the Republican party in 1856 by the men who were not satisfied with the attitude of either the Democratic or the Whig party in regard to the extension of slavery. As a rule, however, each old political party adds to the list of principles and policies which it advocates a view upon each great new question in accordance 
with the opinions of a majority of its members, and, with some slight changes and realignment of dissatisfied members, old parties go on representing their membership upon the new questions as well as upon the old questions in reference to which their parties were organized. In time, as the original questions which led to the formation of a party disappear, the party continues with an organization representing its members no longer for the specific purposes which brought them together, but for the new purposes which they have agreed upon through the processes of their party organization and activity.

Many very good and public-spirited men have deplored the existence of parties, and some of them prefer to stand altogether aloof from political parties and to exercise their right to express their opinions by voice or pen or print, and to vote with entire personal independence and without being either trammelled or helped by the coöperation of others.

As I have tried to point out, however, political parties are the natural product of evolution in the process of popular government; they are not merely the best and most practical way in which 


\section{THE CITIZEN'S PART IN GOVERNMENT}

the operations of popular government can be carried on, but they furnish the only way to carry on those operations so far as we can judge from the experience of the world up to this time. In no large country has any real popular government ever existed for any considerable time without them. They exist in England, France, Germany, Austria-Hungary, Italy, in all the constitutional governments of Europe, and in the Latin-American states, with variations depending upon the characters of the different peoples; and in every case they assume more definite form and more clearly recognized functions as the country progresses from the status of personal government to government of principle and policy. As popular government develops, in every case political parties develop, and in every case the longer the operations of popular government have continued and the more perfect is the expression of public opinion and will, the more highly developed in the true sense is political party organization.

It is, of course, highly important that the voters of a country should hold themselves at liberty to condemn by their votes any party with whose policy they do not agree, or which is false to its pro- 
fessions, or whose candidates for office are found to be unfit to truly represent the principles professed; nevertheless, the great mass of the people of the United States at every election go with one of the great parties or the other, and the great mass of the voters of each party stay with their party election after election. They approach every election with a presumption in favor of the policies advocated by the party to which they have adhered in the past. As to the majority of them, that presumption is never overcome. Their minds are most receptive to arguments and persuasion coming from their own party associates and in favor of their own predilections. The habit of reliance upon party leaders; instinctive loyalty to old comrades in former political struggles; the natural reluctance to break old associations and form new ones; and often the predisposing effect of inherited opinions and youthful training-all combine to make men vote ordinarily with their party. This settled tendency makes the determinations reached in the councils of the great political parties the most important and dominating factors in determining the course of popular government, and renders participation in party action the most 


\section{THE CITIZEN'S PART IN GOVERNMENT}

effective way to reach the mind and influence the action of the mass of voters. The great work of popular government is done in the associations and primaries and caucuses and conventions, in the conferences and discussions and canvassing and personal association, in the private meetings and public meetings, in the convention committees, in the draughting of platforms, in the struggles between candidates for nomination, in the efforts to educate and convince and persuade voters, and in all the great and complicated process which goes on incessantly within each party in every village and town and city and State, culminating in the submission of the work of the national convention to the voters of the country at large, and, upon one side or the other, determining the legislative and executive policies of the country.

I have no doubt that the American who feels the responsibilities of his citizenship can do his duty as a part of the governing people better by entering into the organization of one of the great political parties than in any other way. The better educated, more intelligent and more active he is, the greater is the reason why he should seek for his powers the immense increase of effective- 
ness which comes from association, combination, and organization. There are many abuses of party power and in party management in the United States; but the American who stands apart and criticises or condemns the conduct of political parties may well be answered, "Yours was the responsibility and you have wholly failed to discharge it."

We sometimes hear it said by intelligent and educated men that there is no opportunity for them to do anything in party politics because the machine controls everything, and no one who is not in the machine has any chance-that is to say, that the men who for the time being hold the party offices will control the party action, and the voice of an individual new recruit in the party ranks would not exercise any control. This is wholly fallacious. There never is a party organization or a so-called machine which cannot at any time be turned out of power if the rank and file of the party choose to turn them out; and there never is a time when a man of character and ability entering into the active work of a party cannot gain in full measure the influence and power to which his ability entitles him, or cannot contribute ma- 


\section{6 \\ THE CITIZEN'S PART IN GOVERNMENT}

terially to a change of control, provided he is willing to take the pains and give the time and effort necessary to the creation and exercise of influence among the members of the party. Of course a new recruit cannot step into a new association with a great number of people and immediately dictate what they are to do. Time and long-continued effort and long association, through which come confidence in a man's sincerity and respect for a man's opinions and a desire to comply with a man's wishes, are necessary to the exercise of that kind of power; but the same things are necessary to the exercise of influence and power in any of the affairs of life which involve the conduct of others. If any American citizen is willing to make the same sacrifice of personal comfort and convenience and employ the same ordinary means to make himself an active force in politics which he would employ to make himself an active force in business, or in the church, or among the members of any profession, or in any kind of enterprise which involves the action of a large number of men, no party machine can prevent and ordinarily no party machine wishes to prevent him.

We often hear remarks made which indicate an 
impression that politicians are rather a low set of fellows, with selfish aims and corrupt practices, who manipulate party politics for their own advantage, and that the less self-respecting gentlemen have to do with them the better. If that is ever the case, and it undoubtedly is the case at some times and in some places, it is always because at such times and in such places political control is allowed to go by default. Such a condition of political affairs is always due to the fact that the citizens who are honest, upright, and publicspirited, who would not prostitute party power to personal advantage, who would not make a party organization a corrupt combination to secure place and profit, fail in the performance of their public duty and permit the party organization which limits and restrains the exercise of their political powers to remain in the hands of unworthy and self-seeking men. There is no party in which the great body of the voters desire that kind of control, and it cannot exist unless the voters of the party, and the citizens who ought to be active in exercising the powers of the party, fail through indifference and unwillingness to spend the necessary time and take the necessary trouble to exer- 


\section{THE CITIZEN'S PART IN GOVERNMENT}

cise the powers that lie within their reach. I have said that there are serious evils incident to the management of our political parties, and some of these I shall presently mention; but they are all evils which would be readily remédied if the citizens generally who are in agreement upon the principles of the respective parties would recognize their responsibility and perform the political duties which rest upon them as citizens. The fact that such evils exist, instead of being a reason for not engaging in party activity, is a reason for engaging in it. Such a fact presents a clear and imperative duty to remedy the evil; and that duty rests not merely upon the men who already have membership in the party, but upon all men who agree in general with the principles of the party, and who therefore ought to look upon the party officials and managers as their agents and to hold themselves responsible for their agents' character and conduct.

Another reason or excuse for not taking part in political affairs is the direct reverse of those that I have mentioned: it is that party management is satisfactory; that matters go along very well, and that a man does his duty to his party if he supports 
its ticket with his vote and perhaps contributes his fair share toward the payment of its expenses. This position can never be maintained. It means, in the first place, that the man who takes it is willing to have the greater part of his duty as a selfgoverning citizen done for him by others, and it means also that the power and efficiency of the party in working out the problems of government and in advocating and enforcing the conclusions which it reaches are reduced by the desertion of one of its elements of power-that is to say, the ability and force of character of a part of the men who ought to be engaged in its work.

None of these reasons for not taking part in party politics is ordinarily the real reason. The real reason is that men are unwilling to spend the time and the money and the labor necessary for the due performance of their duties as citizens; that they prefer to attend to their professions, their business, their pleasures, and allow others to govern them rather than to take part in governing themselves; that they are willing to permit the great struggle which is continually proceeding for the preservation and protection of their property, their liberty, their opportunities, for sound prin- 


\section{THE CITIZEN'S PART IN GOVERNMENT}

ciples of finance, for the preservation of society, for the correction of social and political and business evils, for the punishment of wrong-doing, for the furtherance of justice and the maintenance of peace and righteousness, to go on without any help from them. They are willing to let the great mass of men upon whose education and clear and reasonable understanding of governmental questions the whole structure of free government depends go without any help from their education and intelligence. They are willing to pursue a course which, if shared in by the rest of their countrymen, would bring our constitutional government to an immediate end, wreck our prosperity, and stop our progress. They are willing to depend, for the continuance of everything they have of value in life, upon their confidence that others will be more public-spirited and unselfish and willing to take trouble in performing their public duties as citizens than they are themselves. 


\section{III}

THE - DUTIES OF THE CITIZEN AS A MEMBER OF A POLITICAL PARTY

It is quite simple and easy for any intelligent young man to take part in the activities of a political party in the United States. He has only to select the party the ascendency of which he considers most desirable, and let the recognized party officials of his own home know that he is willing to work. He will promptly find himself admitted to membership in whatever may be the simplest form of political organization or association in the locality, and will find himself provided with plenty of work to do. He cannot begin by leadership or by dictating party policies, and he probably cannot assume in the beginning any such position of superiority as he may think his education and intelligence entitle him to have. The work in which he will be engaged at first may be simply the details of local organizations, which will perhaps seem of 


\section{THE CITIZEN'S PART IN GOVERNMENT}

little consequence; or engaging in struggles between candidates for small offices, in which he does not take very much interest; or canvassing from house to house to ascertain the political affiliations or preference of the residents. It may be very far from that advocacy of principles and influence upon the policies and direction of government in which he would like to engage. He may, however, be sure that he will ultimately find the exact level and rise to the full height of opportunity and influence and dignity of employment to which his abilities, character, and devotion to his duties entitle him. If he is able and willing to render effective service, he will gradually find himself moving along until he is at last engaged in the most important duties on the broadest fields of political action. In the meantime, or if he should never rise above mere local activity, let him remember that the first and chief duty of citizenship is to serve in the ranks-not to await some great and glorious occasion to win fame and power. It is the active service of the men in the ranks that makes the difference between popular self-government and popular submission to an absolute monarch. Without the great body of workers who 
never rise to leadership popular government would be as impossible as a successful army composed entirely of officers.

In the performance of the simple duties of the political beginner there are certain principles of conduct so indispensable to usefulness that observance of them is a clear duty.

Men influence the conduct of others chiefly through personal association and intercourse. There is such a preponderance of good in human nature that association with men ordinarily begets a liking for them. As men come to know each other each comes to receive from the others the respect and confidence to which he is entitled; his character and his opinions insensibly acquire their due weight and influence. It is not the stranger who says, "Go there," or "Do that," who is obeyed; but it is the old acquaintance who says, "Come with me," or "Let us do thus and so," who is followed. The knowledge of the tendencies and prejudices of men acquired through personal acquaintance makes the suggestion of a wish from a friend often of greater weight than the most eloquent speech or the most profound essay from a stranger. This power of association is the chief 


\section{THE CITIZEN'S PART IN GOVERNMENT}

thing which enables political organizations, even when they are going wrong or in bad hands, to resist attacks from without, even from the best and most highly respected citizens, when these occasionally and for the moment are moved to instruct the men actually engaged in political affairs as to what they should and should not do.

There is no monopoly of this power of association. Unselfish and public-spirited men can qualify themselves to exercise it if they take the trouble, just as well as self-seeking men of low aims.

To accomplish very much with other men one must have a considerable degree of sympathy with their feelings and interests. The man who never cares or thinks about anything but himself cannot expect anybody to think or care about him. If he has no interest in the hopes and ambitions of others, no consideration for their sensibilities, they will be equally indifferent so far as he is concerned. Political bodies, especially primary political bodies, are made up, to a degree unequalled in any other association, of men of widely varying conditions in life, with different opportunities for knowledge and capacity for reflection, with different prejudices and ways of thinking, differing 
widely in information, in previous reflection, in breadth and scope of thought, in motives, in characters, in tempers, in ambitions. Each one of them is entitled equally with all the others to have his opinions, his wishes, and his ambitions considered; and the feeling that any one gives kindly consideration to them is in itself a great source of influence. The man who has never had anything above a day's wages or a small clerk's salary, or who perhaps has no income but is looking for one, is just as much entitled to aspire to a place in the custom-house, or to a post-office, or to be a letter carrier, as the very successful and able man distinguished in his community is entitled to aspire to be governor or Senator; and the small man is just as much entitled as the big man is to have his aspiration considered and treated as an honorable aspiration. The small trader who hopes that the legislation and administration of government will be such as to promote the prosperity of his little business is just as much within his rights as the great banker who hopes for currency legislation or the great manufacturer who hopes for tariff legislation beneficial to his business. Sympathetic recognition of such considerations is a 
natural and necessary basis for influence and leadership among political associates.

A rightly constituted man brought into association with a great number of others cannot fail to acquire some degree of proper humility. It matters not how well educated or intelligent a man may be, the combined experience, knowledge of life, range of thought, fertility of suggestion, thoroughness of criticism, to be found in any great body of men taken together are so far beyond him that he is bound gradually to take an attitude of receiving and learning as well as endeavoring to instruct and lead. He will thus escape from the fatal attitude which ruins one's influence with others by giving an impression of assumed superiority in wisdom or virtue.

In order to secure united and successful action for any purpose the members of a political party must learn to subordinate minor differences in order to combine for the advocacy and promotion of more important matters in which they agree. That is essential to the maintenance of any political organization, as indeed it is essential to successful combination in all human affairs. The concerted action of many men of different interests, 
impulses, opinions, and desires is essential to the accomplishment of any result under popular government; and that concerted action cannot be attained except by continual and mutual compromises. There is no quality in a people more important for success in popular self-government than that practical, common sense which makes them capable of such practical compromises; and every one engaged in political affairs is under a duty to make such fair concessions from his opinions and desires as may reasonably contribute toward bringing out practical and effective results in common action. Of course this does not mean to compromise character. Every man, however, should be careful not to deceive himself into supposing that to be a matter of conscience which is really only a matter of pride of opinion, or determination to have one's own way.

In politics, as in everything else, a man ought to be thinking about his work and not about what he is going to get out of it; to be intent on succeeding in his undertakings rather than upon the appearance that he is making or the credit that he is going to receive. That is an essential condition to success in all the arts which deal with human nat- 
ure as their material. I have often noticed at the bar that the advocate who is thinking about making a fine speech never makes a lodgment in the mind of either the court or the jury; they may admire the speech, but they are neither convinced nor persuaded. This is true at the bar, in the pulpit, and in the lecture-room. It is equally true of literary style; all obtrusively fine writing is ineffective. And this is true in politics. I do not mean to insist upon an impracticable altruism, or to exclude an honorable ambition to succeed and to have the reward of good, effective work, which comes from the favorable opinion of one's fellows and a general recognition of one's service. Recognition and appreciation are properly gratifying to every one; but that should be a secondary object if a man is to do the best type of work. The primary object with every man should be to do the work that comes to his hands just as well and thoroughly as he possibly can do it; and there is one certain reward for work so done-in the satisfaction that the man himself feels in having done good work. Every man should rely for the appreciation and recognition of his service, not upon his own estimate of it, but upon the estimate of 
others; no man can properly judge of his own merit or the value of his service. It will often happen that particular things a man does may not receive from others the credit to which they are entitled; but it will also happen that he will get more credit than he is entitled to for other things that he does; and, in the long run, every man may be sure that he will receive all the credit to which he is entitled without any attempt on his part to influence the judgment of others or to force upon them his own estimate of himself. The man who engages in political work with the primary idea of getting office may succeed in getting the office; but he is likely to lose what is of far greater value than any office-the good opinion of the community in which he lives-for the people of self-governing communities ordinarily possess a strangely unerring insight which detects the spirit in which such a man works and classifies him as a mere politician in the bad sense of the term and stigmatizes him as an office-seeker.

The career and influence of such a man, moreover, tend to promote the kind of political activity which is the most injurious and demoralizing in popular government. 
It appears from what I have already said that there are three quite distinct stages in the development of self-government. The first and lowest is that in which the people of a country divide with sole reference to their partisanship for particular persons whom they desire to put into power. In its worst form this kind of partisanship is so completely exclusive of consideration for public good that the contest for personal ascendency often merges into violence and civil war and continuous revolutionary attempts. This condition was once widely characteristic of Latin-American republics, and some of them are still at that low stage of development, although many of them and the most important have happily passed out of that stage and have come to regard the choosing of officers as the means of giving effect to policies rather than as being itself the object of popular government. Those countries have had one preëminently great and noble example.

José de San Martin was born in Argentina, served with distinction under the Spanish flag in the Napoleonic wars, and returned to his native land at a critical period of the South American struggle for independence. Everywhere except in 
the United Provinces of the River Plate the early revolutionary efforts had been suppressed by Spain. The old viceroyalty of Peru, strong in its mountains, in its army, and its command of the sea, was the centre of reactionary power. Impregnable there against attack, it seemed that Spain could choose her own time to sweep down over the old trade route by which the precious metals of Peru had found their way to the commerce of the Plate and to destroy all that was left of South American freedom. San Martin conceived the great design of leading an Argentine army across the Andes, conquering the Spaniards in Chile, setting that country free, creating a navy on the Chilean coast, destroying Spanish naval power in the Pacific, and, having acquired command of that ocean, attacking and overcoming the Spaniards in Peru along the same line of approach from the west that had been followed by the old conquistadores. He executed his design with amazing audacity, tenacity of purpose, power over men, organizing skill, and self-devotion. He overcame obstacles apparently insuperable, achieved one of the really great military and political movements of history, and ruled in Lima as " Founder 
of the Liberty of Peru." In the meantime, Bolivar had led successful revolution in Venezuela and Colombia, and the union of the northern and southern patriot forces seemed about to complete the eradication of Spanish rule in the Southern Continent.

The character and conduct of Bolivar soon made it plain that he regarded San Martin as a rival, that they could not coöperate, and that the continuance of both commands meant strife for personal power between the two leaders-to the destruction of the patriot cause. Then San Martin gave an example of self-sacrifice more admirable than his victories or his strategy. In order that a united patriot army might oppose the forces of Spain, he effaced himself, laid down his command, his titles, his dignities, and power. He sent to Bolivar his pistols and his war horse with this note:

Receive, General, this remembrance from the first of your admirers, with the expression of my sincere desire that you may have the glory of finishing the war for the independence of South America.

And he left the scene of his great achievements never to return. 
Bartolomé Mitre says truly:

History records not in her pages an act of self-abnegation executed with more conscientiousness and with greater modesty.

San Martin died misunderstood and in exile. To the generals and politicians who were plunging the South American republics into continual bloodshed for their own selfish ambitions, and to their adherents, the spirit of self-assertion which demands power and fame seemed admirable and the spirit of self-effacement for a cause seemed weakness. But as the people of those countries have risen to a higher plane of duty and honor, there has come the realization that the great South American - the one worthy to be named with Washington as the example and inspiration of patriotism - was the modest soldier who cared more for his cause than for his office, and who was willing not merely to wield power, but to give up power, for his country's good.

It has always seemed to me that Mr. Tilden pursued a very patriotic and commendable course when the election to the Presidency was in question between him and Mr. Hayes in 1876. The election was very close and there was no doubt 
that if all the votes actually cast in the Southern States received effect Mr. Tilden would be declared elected; but many votes had been thrown out by the State returning boards in the South on account of alleged fraud and intimidation that had prevented the casting of other votes, which, if cast, would probably have caused a different result. There was a question that inevitably would have resulted in civil war in any country where the personal idea was predominant in politics, and there were in this country many men of high character and standing who urged that Mr. Tilden's title to the office should be asserted by armed force; but he was decided and immovable in the position that he would permit no breach of the peace of the country in his behalf, whether he got the Presidency or not. The questions were finally submitted to a special court devised for the purpose, and that court by a majority of one decided in favor of Mr. Hayes. So Mr. Tilden lost the Presidency; but he gained what was of far greater value-a title to the esteem and gratitude of all good citizens. He probably rendered a greater and more permanent public service than by anything he could have done as President. 
The second stage of development in popular government is reached when the people of a country have passed beyond exclusive attachment to individual fortunes and, turning their attention to questions of principle or policy or material interest, have arrayed themselves in support of their various opinions or desires, but have not yet reached the point where they are able to subordinate minor considerations upon which they differ to those of primary and vital importance upon which they agree. In this stage of development many groups make their appearance, each having some controlling idea which it regards of primary importance. Sometimes those ideas are local; sometimes they are religious; sometimes they relate to special class or business interests; sometimes they relate exclusively to some special political, social, or economic question. The most conspicuous result of such a condition is found in the election of legislative bodies, in which representatives of all the different groups are found, and in which no party has a majority; so that no affirmative legislation is possible except by trades and combinations between different groups. One effect of this legislative condition is that in coun- 
tries where the executive is responsible to the legislature the executive cannot depend upon steady and constant support from the law-making body in any line of policy, because the combination of groups is continually changing and the executive that has a majority to-day may find itself in the minority to-morrow. There are some countries where this government by groups exists, in which the constant fluctuation of legislative combinations and majorities leads to very frequent changes in the responsible ministry; and in those countries good administration is almost impossible, not only because there can be no continuity of executive policy, but because the heads of the executive departments who constitute the ministry are seldom able to do more than to begin to learn their business before they are turned out to make place for new men, who have again on their own account to begin the same process of learning the business. The most corrupt and unsatisfactory period in the government of Great Britain was when Parliament was divided into groups in this way.

Great Britain has passed out of that stage into the third and higher stage of development, in which two great political parties oppose each other 
upon fundamental differences, the members of each differing in many respects among themselves upon minor questions but not allowing those differences to break up their party. This condition now exists both in England and in the United States. Under it the executive government has the continuous support of its own party, and so long as that party is in the majority there is a united and effective government. When that party ceases to command the support of a majority of the people, it goes out of power and the other party comes into power to receive an equally effective support until another change comes.

The course of evolution in popular government is thus from the formation of an indefinite number of individuals into parties with the idea of putting men into office to the formation of an indefinite number of parties grouped especially with regard to advancing special interests and ideas, and thence to the formation of two great parties representing fundamental differences in the general principles and policies of government. The development is from the unmixed preponderance of personal and selfish motives to the predominating motive of common good for the country. 


\section{THE CITIZEN'S PART IN GOVERNMENT}

Since personal selfishness and desire for personal aggrandizement are by no means eradicated from human nature, there is a constant tendency in political parties to revert to a lower type. Party leaders frequently use for their own personal advantage the power conferred upon them for advocacy of those ideas which the members of the party believe to be for the best interests of the country. This tendency is promoted by every man who takes part in political activity with the primary purpose of getting an office for himself, and it is discouraged and reduced by every man who takes part in political affairs with the primary purpose of doing effective service to advocate the principles that he believes in and to elect officers who will apply those principles, leaving the question of his own personal reward and advantage to come from such recognition of his service as others may think it deserves.

The tendency to revert to the lower type of organization which concerns itself solely in the obtaining of office is one of the evils to which I referred in a former lecture when discussing the objections sometimes urged against taking part in politics. This evil has been very prevalent in 
American politics, and it is still prevalent, although to a less extent than formerly. With us it takes the form of grafting upon the great parties of voters organized for the advocacy of certain declared principles an organization of active party workers for the distribution of offices.

The process is a very plain and natural one. The object for which the voters have associated in a party is to bring about the application of certain principles and conformity to certain policies in carrying on the government of the country. The only way to secure that is by agreeing upon and voting for candidates for office who, if elected, will observe those principles and follow those policies. There is an immense number of these offices, of varying grades, from the Presidency down; there are national and State, county and city, town and village officers, legislative and executive and judicial officers; great numbers of clerks and collectors and inspectors and watchmen, agents of different kinds, mechanics, and skilled and unskilled laborers. Comparatively few of these, and generally the most important, are actually elected by the people; the great mass of them, particularly of the minor officers and employees, are 
selected and appointed by the officers who have already been chosen by election, and about this selection and appointment the people have nothing to say except as individuals among them may make requests or recommendations to the appointing powers.

The proper and necessary operations of a party cover a wide field of activity. They include the selection of candidates for the elective offices. This is done sometimes by means of the direct expression of the wish of the voters of the party, but more frequently by having the voters of the party elect delegates to conventions which meet and select the candidates. The operations of the party also include the consideration, discussion, determination, and statement of the position of the party upon the important public questions of the day. This also is done by the same conventions which select the candidates. The operations of the party also include appeals to the people to vote for the candidates which represent the party. These appeals are made by personal canvasses from house to house, by public meetings and speeches, by the circulation of campaign literature through the mails and through the columns of the 
press. There are also included the general and concerted efforts to get out the vote, to see that the voters of the party do not, through indifference, stay at home and neglect to vote at all; and also the manning of the polls under concerted and systematic arrangement, for seeing that the voters of the party are not denied their rights at the polls, and that no fraud is perpetrated or undue advantage is taken by the members of the other party in the voting or the counting of the vote. All these things require an immense amount of hard work and the participation of a great number of men, and all these workers have to be directed. System, organization, control, leadership, are absolutely necessary; leadership of opinion in the framing of platforms and in the selection of proper candidates, and leadership of administration in the carrying on of the work.

This enormous mass of work preceding and leading up to the exercise of the franchise and, so far as we can judge both from reasoning and experience, essential to make the ballot effective, is done by volunteers, who receive no compensation from the State for the public service they are rendering and must be inspired by some other motive. 
So well established is the understanding that these are the processes by which Americans work out the results to be confirmed by the ballot that laws have been made in the larger States, where political affairs are most complicated, to regulate proceedings in the political parties by primary laws designed to prevent fraud in the selection of delegates to conventions and in the choice of candidates.

It is not at all unnatural that among the men who do this voluntary work resulting in the selection of candidates and their election to public office there should be many who desire to be appointed to the offices and employments at the disposition of the officers so elected. Unfortunately, there has grown up in the United States a practice of considering the service of party workers leading to the selection and election of candidates as a controlling reason for the appointment of those party workers to the places at the disposal of the candidates after their election; and that practice has resulted in the prevalent understanding that there is an implied agreement by every successful candidate for an elective office to reward support by exercising his governmental powers for the 
appointment and employment of his supporters. The practice originated in the complicated political activities of the great States of New York and Pennsylvania early in the last century. It was extended to the Federal Government under the Presidency of Andrew Jackson, and the most familiar statement of it was made by William $\mathrm{L}$. Marcy in the Senate of the United States in the debate on Jackson's nomination of Martin Van Buren to be minister to England. Marcy said:

It may be, sir, that the politicians of New York are not so fastidious as some gentlemen are as to disclosing the principles on which they act. They boldly preach what they practise. When they are contending for victory, they arow their intention of enjoying the fruits of it. If they are defeated, they expect to retire from office; if they are successful, they claim, as a matter of right, the advantages of success. They see nothing wrong in the rule that to the victor belong the spoils of the enemy.

The application of this principle is not confined to the demand of the individual party worker upon the successful candidate for a recognition of his personal service; it goes a step further back and affects the action of the party worker in the selec- 
tion of party leaders who will support and press the party worker's claim to recognition from the public officer when elected. It determines the selection of the party committees and their chairmen, from the lowest local committee in the assembly district or town or village, who are expected to press the claims of the men who elect them for appointment and employment, up through the county and State committees to the national committee and the chairman of the national committee, who directs the vast machinery of the Presidential election.' It converts the whole party organization commissioned by the voters of a party to conduct the systematic proceedings which shall enable them to maintain and advance their political principles by their votes, into an organization primarily for the parcelling out of offices, and incidentally for the promotion of party principles so far as may be necessary to keep the voters of the party from repudiating the party organization.

Several results follow from the application of this principle.

It leads to a selection of candidates for office based primarily on their supposed willingness to carry out the implied obligation to use their off- 
cial powers, if elected, for the reward of their party supporters, the fitness of the candidates and the benefit which the public will receive from their service being considered only when it is probable that an election will be close and that every vote will be needed.

It leads to the exercise of the appointing power by the public officers who are elected in this way, not with reference to the public service which the appointees can render, but with reference to the political service which they have already rendered in the selection and election of the officer. It goes further than this in its effect upon the exercise of official power, for by natural extension it is made to cover an assumed obligation on the part of public officers in the performance of their other duties to act, not with reference to the public good, or for the promotion of the great policies of a party, but in such a way as to secure the greatest number of offices with the greatest possible emolument to the members of the party organization. This obligation is assumed to rest upon legislators, and sometimes even upon judges.

It demoralizes the public service, by establishing a tenure of office which depends not upon 
faithful and efficient service to the country, but upon service in party primaries and caucuses and conventions; and it tends to make the elected officers feel responsible not so much to the public opinion, which judges of their fidelity and efficiency, as to the party managers who are to determine whether they shall be renominated or not. This cannot fail to result in poor service. It is impossible to have good service in any business, public or private, unless the character of the service itself is to determine whether it shall continue. This has been very well illustrated in a way in which any one who has been in the habit of frequenting the city of New York during the past twenty years can appreciate. That city formerly had a street-cleaning department managed by a bi-partisan police board composed of two Democrats and two Republicans. The members of the street-cleaning force were appointed for the political committees of the two parties. The party committees and the party leaders in the different assembly districts in the city were furnished with tickets, which they distributed to their supporters. On the presentation of these tickets the holders were treated as entitled to employment on the 
force. Their retention on the force depended entirely on the favor of the party managers from whom they got their tickets-not at all upon the way in which they did their work. They were lazy, inefficient, undisciplined, and without effective supervision, because under that system no supervision could have any effect; and the streets of New York were continuously disgracefully filthy. The evil became so great that the legislature at Albany changed the law and provided for a superintendent of street cleaning; and about that time one of the occasional revolts of the city of New York occurring, a good business man was made mayor and he appointed Colonel George E. Waring, of Newport, a distinguished sanitary engineer, superintendent of street cleaning. Colonel Waring threw overboard the whole existing system, established a rigid system of supervision, paid no attention to so-called political claims, and promptly dismissed every man who was found to be lazy or inefficient. Within a few months he had an active and effective force; the streets of the city were swept clean and kept clean, and they continued so until Colonel Waring's lamented death and for a long time after, until the system which 
he had inaugurated gradually fell into disuse and the old habit of using the street-cleaning department as an opportunity for giving employment on the grounds of party service was resumed; and the city has become again disgracefully unclean.

The application of the principle announced by Senator Marcy tends to weld the official personnel of party organization into a compact body of men, who, depending upon each other for personal advancement, stand by each other at all hazards and oppose the power of organization to every effort on the part of the mere voting members of the party to take any course in party action which may interfere with the regular business of bartering offices for support and support for offices. As the men who form such a compact official organization expect to make their living by it, they are able to devote their entire time to the manipulation of party affairs, and in that way have a great advantage over the business and professional men, who must devote themselves to their business and professions and can give but a small part of their time to political activity.

Another and peculiar result of this system is the creation, in some places where the system is in full 
force, of double governments, one carried on by the executive and legislative and judicial officers provided for by law, the other carried on by the official organization of the party which happens to be in the majority, under the direction of the party leader, who controls the action of the lawful officers. There have been cities in which substantially the whole board of aldermen have invariably and without question voted as they were directed by the leader of the majority party in the city, and upon all important questions have waited habitually to get his orders before voting; in which the executive and administrative officers have sought his instructions rather than the instructions of the mayor, and in which the minor judicial officers have uniformly conformed their judgments to his wish. There have been States in which the party leader has habitually determined what bills should and what bills should not be passed by the legislature, and in which the majority of the legislature have uniformly sought and obeyed his instructions. The lawful officers are thus subservient to the party leader, because they hold their offices at his will by virtue of the compact organization behind him, which will 
control future conventions, nominations, elections, and appointments.

A peculiarity of this kind of government is that the real governing power is without legal responsibility and is practically free from statutory legal restrictions. The party leader combines legislative and executive functions, and he often trenches upon judicial functions. He acknowledges no obligations to the public; his obligations are simply to secure offices for his followers. To pay a legislator for his vote, or an executive officer for the exercise of his discretion, is a felony, and for an officer to receive a bribe is a felony; but the party leader is under no legal prohibition against receiving any consideration or acting upon any personal interest in the exercise of his power, which controls both the vote of the legislator and the discretion of the executive. The only danger he has to apprehend is that the voters of his party may repudiate his candidates, and against that he is measurably protected by the fact that such action will be at the cost of putting the government into the hands of those who would administer it upon principles and according to policies which the voters consider unsound and injurious. 
Such a system is not essential to effective party organization. On the contrary, it tends to prevent effective party organization; it tends to keep out of the organization the men whose service would be most effective, and to make more difficult the work of the men who take part in the organization with the real purpose of making it accomplish its legitimate results. It tends to make an organization which does not really represent the voters of the party, and to leave the voters of the party without any genuine representative organization. It results in elections in which the voters of the country have no opportunity to express by their ballots their real choice of candidates or their real opinions upon public questions. It weakens one of the great agencies for carrying on a popular government, and introduces an injurious imperfection into the method by which alone public opinion can be made effective through governmental machinery.

The whole system is pernicious and discreditable to American citizenship. It ought to be done away with and political parties ought to be brought back to the sole performance of their proper function as organizations for the promotion of prin- 
ciples and policies, free from the control of mere office-trading combinations.

It is, however, mere folly to say that the existence of such an evil furnishes a reason why. educated, self-respecting Americans should not take part in the work of the political parties with which they vote. On the contrary, the existence of the evil presents a manifest and urgent duty to the conscience and patriotism of every competent American.

The duty is to enter into the work of party activity and help make the party organization what it ought to be. The duty rests upon each intelligent citizen in his own community to incite the voters of the party he believes in to take charge of their own affairs, and to substitute party organization and party leadership which is really representative of them in place of the party organization and the party leadership which are maintained by the distribution of office for the sake of office. 


\section{IV}

\section{THE GROUNDS FOR ENCOURAGEMENT}

The third lecture of this series set forth the evils resulting from the usurpation of party control by a mere office-bartering combination which takes the place of organization for legitimate party purposes, and the citizen's duty to aid in doing away with such usurpation.

Such a change is entirely practicable. To doubt that it can be made is to doubt the capacity of our people for self-government, because the change requires only such willingness to perform the duties of citizenship as is essential to the successful exercise of popular self-government. It cannot be produced suddenly or without systematic and continuous effort, or by mere exhortation or protest. It must come slowly, in the ordinary course of political development. It cannot be expected that the men who compose party organization will become suddenly altruistic. The evil to be dealt 
with is a strong affirmative assertion of the selfinterest of the old type of party organizers, and it cannot be overcome by a mere negative. It must be met by a stronger assertion of the more powerful interest of the party voters. Such a system is not necessary to secure the filling by a member of the dominant party of every office the duties of which bear any relation to the effectiveness of party policy; on the contrary, it tends to the filling of offices by men who are indifferent to party policy, and whose allegiance is solely to their own personal interest. The destruction of the system will not exclude party workers from public office; it will simply deprive them of their claim to public office when they can not justify it on public grounds.

The obnoxious system already has been greatly reduced in its scope and power. The modern civil-service method of selection for appointment has withdrawn from the bargain counter a great mass of governmental offices and employments individually of minor importance but in the mass of very great importance. The governments of our insular possessions have been established and maintained without any regard whatever to the 
payment of political debts. No attention is paid to party affiliation or service in appointments in the military and naval services. Within the past year the consular service has been brought under new regulations, by which all the higher places are filled by promotion on the basis of efficiency as established in the service, and the lower positions are filled by original appointment upon thorough examination. The fourth-class post-offices have been brought under a new rule, which makes the continuance of the office depend upon the merit of the officer rather than upon political favor. Thus, the stock in trade of the office business is being rapidly reduced. Throughout the Federal service the theory of implied obligation to pay political debts with offices is gradually and very generally weakening and tending to disappear. The widespread pressure for direct primaries indicates a determination among party voters to secure a real expression of their own will in the selection of candidates. It needs only to continue the process that is now going on in order to free these great agencies of government from the false organizations which have so long oppressed them, as the Old Man of the Sea on the 
neck of Sinbad; to make our party organizations generally, as they already are in some places, really representative; and to make party leadership depend, as it does now in some States, upon leadership of opinion, upon the confidence of the community, upon political wisdom, upon superior ability to assert and maintain the principles and policies of the party.

In the whole field of popular government I am convinced that one of the plainest duties of citizenship is hopefulness, and that pessimism is criminal weakness.

If one is to judge the world and the conduct of men by comparison with a standard of ideal perfection, of course everything will be found wrong. If the question we ask is whether the world, or any community in it, is good or bad, right or wrong, we must recognize a painful degree of error and selfishness, and injustice and cruelty, and indifference and ignorance.

The true question, however, is not what the world is, but what its tendencies are. Is it moving toward better things, or worse? Is the level rising, or falling? Mark the condition and character of civilized peoples in successive centuries or gen- 
erations, and see whether liberty and justice and righteousness have been gaining, or losing. See whether education has gained ground, or lost; whether men generally are more, or less intelligent; whether they have grown more cruel, or more kind-hearted; more selfish, or more regardful for the rights of others; whether government is more pure, or more corrupt; whether the laws are more, or are less just-more, or less respected. Thus you will learn whether to look to the future with confidence and hope, or with distrust and with forebodings.

You will find that such an inquiry yields a most cheerful and encouraging response as to the condition and probabilities of popular government.

There is not one element of character, of capacity, or of practice going to make up what government ought to be in which there has not been steady and great advance in the progressive development of government by the people.

It is impossible to read an account of the life of the people of any civilized country in any past century without finding an amazing degree of cruelty, of oppression, of immorality, of corruption, and of class privilege regardless of common right, 
which has now been substantially done away with.

To go no farther back than the early years of the last century in England, the reform of the criminal law, under which more than two hundred offences were punished by death; the struggle for Catholic emancipation; and the revolution in parliamentary representation, which destroyed the rotten borough system and transferred power from the landed aristocracy to the great middle class in England, mark the positions from which popular government has advanced.

If we go back to the early days of the eighteenth century John Morley says:

A candid and particular examination of the political history of that time, so far as the circumstances are known to us, leads to the conclusion that Walpole was the least unscrupulous of the men of that time.

\section{Yet he says:}

*** That Walpole practised what would now be regarded as parliamentary corruption is undeniable. But political conduct must be judged in the light of political history. Not very many years before Walpole a man was expected to pay some thousands of pounds 
for being made Secretary of State, just as down to our own time he paid for being made colonel of a regiment. Many years after Walpole, Lord North used to job the loans, and it was not until the younger Pitt set a loftier example that any minister saw the least harm in keeping a portion of a public loan in his own hands for distribution among his private friends. For a minister to buy the vote of a Member of Parliament was not then thought much more shameful than almost down to our own time it has been thought shameful for a Member of Parliament to buy the vote of an elector.

\section{Lecky says of Walpole and his times:}

He governed by means of an assembly which was saturated with corruption, and he fully acquiesced in its conditions and resisted every attempt to improve it. He appears to have cordially accepted the maxim that government must be carried on by corruption or by force, and he deliberately made the former the basis of his rule. $* * *$ The systematic corruption of Members of Parliament is said to have begun under Charles II, in whose reign it was practised to the largest extent. It was continued under his successor, and the number of scandals rather increased than diminished after the Revolution. Sir J. Trevor-a Speaker of the House of Commons-had been voted guilty of a high crime and misdemeanor for receiving a bribe of 1,000 guineas 


\section{THE CITIZEN'S PART IN GOVERNMENT}

from the city of London. A Secretary of the Treasury -Mr. Guy-had been sent to the Tower for taking a bribe to induce him to pay the arrears due a regiment. Lord Ranelagh, a paymaster of the forces, had been expelled for defalcations in his office. In order to facilitate the passing of the South Sea Bill, it was proved that large amounts of fictitious stock had been created, distributed among, and accepted by, ministers of the Crown. Aislabie, the Chancellor of the Exchequer, was expelled, sent to the Tower, and fined. The younger Craggs, who was Secretary of State, probably only escaped by a timely death. His father, the PostmasterGeneral, avoided inquiry by suicide, and grave suspicion rested upon Charles Stanhope, the Secretary of the Treasury, and upon Sunderland, the Prime Minister. When such instances could be cited from among the leaders of politics, it is not surprising that among the undistinguished Members corruption was notorious.

\section{Lecky says, also, of the same period:}

The magistrates were in many cases not only notoriously ignorant and inefficient, but also what was termed "trading justices," men of whom Fielding said that "they were never indifferent in a cause but when they could get nothing on either side." The daring and the number of robbers increased till London hardly resembled a civilized town. "Thieves and robbers," said Smollett, speaking of 1730, "were now become more 
desperate and savage than they had ever appeared since mankind were civilized." The mayor and aldermen of London in 1744 drew up an address to the King, in which they stated that "divers confederacies of great numbers of evil-disposed persons, armed with bludgeons, pistols, cutlasses, and other dangerous weapons, infest not only the private lanes and passages, but likewise the public streets and places of usual concourse, and commit most daring outrages upon the persons of Your Majesty's good subjects whose affairs oblige them to pass through the streets, by robbing and wounding them, and these acts are frequently perpetrated at such times as were heretofore deemed hours of security." *** The more experienced robbers for a time completely overawed the authorities. "Officers of justice," wrote Fielding, "have owned to me that they have passed by such, with warrants in their pockets against them, without daring to apprehend them; and, indeed, they could not be blamed for not exposing themselves to sure destruction; for it is a melancholy truth that at this very day a rogue no sooner gives the alarm within certain purlieus than twenty or thirty armed villains are found ready to come to his assistance."

At the same period the country roads of England were beset by highwaymen. Dick Turpin, Jonathan Wild, and Jack Shepard shared the admiration and sympathy of the people with the dar- 


\section{THE CITIZEN'S PART IN GOVERNMENT}

ing smugglers who waged continual war on all the coasts against the collectors of the Government revenue. The customs of the country permitted, and the laws did not prevent, the plundering of all wrecks upon the coasts. The jails were filthy breeding places of pestilence. There was but little systematic effort for the relief of the insane, the diseased, the injured, or the helpless through infancy or age; and there was but little effort toward education or enlightenment outside of the fortunate few who made up the landed aristocracy.

When we reflect that these conditions existed so late as during the lives of the men who signed the American Declaration of Independence, and draw a comparison with the conditions existing to-day through the development of the same political institutions, under the control of the same race, in England, in the United States, in Canada and Australia, we cannot fail to realize that the evolution of self-government has been accompanied by amazing progress, not only in material prosperity, but in honesty, in humanity, and in the capacity to maintain order and do justice that leads to the higher intellectual and spiritual life of mankind.

In our own country we may take for comparison 
the shameful breach of the terms of Burgoyne's surrender, the refusal of the States to give effect to the provisions of the treaty of peace with England for the protection of the loyalists; the impotence of the Continental Congress, which Charles Lee described as "a stable of stupid cattle that stumbled at every step;" the jealousies, the pettiness, and the narrow prejudice that hampered and almost ruined the work of Washington; the incapacity of administration to which, and not to poverty, was due the distress at Valley Forge, where the footsteps of our poor soldiers could be traced by the blood on the snow, not because there were no shoes and stockings, but because shoes and stockings were not delivered where they were needed.

The humiliating experiences of the second war with England revealed inefficiency and incompetency of Federal administration that would be ludicrous if it were not lamentable.

It would not be possible now to elect such a man as Aaron Burr Vice-President of the United States; or to leave in command of the army a man like Wilkinson, who was known to be in receipt of an annual payment of two thousand dollars 


\section{THE CITIZEN'S PART IN GOVERNMENT}

from Spain while we were in controversy with that country over the possession of Florida, and whose friends defended him by the assertion that while he took the money he did not mean to give Spain any equivalent for it.

Such a condition of affairs as prevailed in our Congress at the time of the Credit Mobilier business could not exist now. The atmosphere which existed in Washington at that time made it possible for a group of men, most distinguished and powerful among the public servants of the nation, to purchase or accept gifts of securities of corporations upon whose interests they were to vote in one or the other House of Congress. The whole tone of the public service was such that their moral vision was obscured. The same men to-day would find it impossible to do what they did then, because there is a clearer air and a better recognized standard of official morality. The conditions which made it possible for the unfortunate Belknap, as Secretary of War, to sell appointments, and for the trusted official aides of the President to be smirched by the whiskey frauds of Grant's second Administration, happily no longer exist, and no longer can exist. 


\section{THE GROUNDS FOR ENCOURAGEMENT 105}

The very nature of the evils which we are now most earnestly calling upon the Government to remedy is an evidence of the advance in governmental ethics and efficiency, for those evils consist very largely of practices which formerly passed unnoticed, while still greater evils engrossed the efforts for reform.

A fair illustration of this is to be found in an old statute of the State of New York. It is entitled "An Act instituting a lottery for the promotion of literature and for other purposes," passed April 13, 1814. It begins:

Whereas, well-regulated seminaries of learning are of immense importance to every country, and tend especially, by the diffusion of science and the promotion of morals, to defend and perpetuate the liberties of a free state: Therefore,

$\S 1$. Be it enacted by the People of the State of New York, represented in Senate and Assembly, That there shall be raised by lottery, in successive classes, a sum equal in amount to the several appropriations made by this act.

The act then proceeds to appropriate the sum of one hundred thousand dollars for the benefit of Union College, forty thousand dollars for the 
benefit of Hamilton College, forty thousand dollars for the Asbury African Church in the city of New York for the purpose of enabling them to discharge a debt and to establish a school, and thirty thousand dollars for the College of Physicians and Surgeons; and it makes certain provisions for the benefit of Columbia College.

There was a tradition among American college men in my youth that old Doctor Eliphalet Nottclarum et venerabile nomen-bought out the interests of the other institutions under this statute and made much money for Union College out of the lottery, doubtless greatly to "the diffusion of science and the promotion of morals."

I have often thought in recent years, when I have seen very good people wringing their hands over the failure of government to wholly suppress gambling in its various forms, that a reference to this standard of the year 1814 showed the diffculty to be, not the decadence of government, but the advance of morals; not the failure of government to perform its duty as well as that duty was once performed, but the greater burden which we are constantly putting upon the Government to make its enforced restrictions upon a minority of 
the people keep pace with the voluntary self-control of the majority of the people.

Many illustrations of the same process ean be found. The objectionable railroad practices which are now so widely and justly condemned, and which furnish so fertile a source of political discussion, are not new practices; they are old practices which formerly passed sub silencio. The railroad rebates which are now forbidden by law, and for which great corporations are being indicted and convicted, are merely a form of the discriminatory rates which once prevailed without objection. Thirty years ago all railroads gave special rates to shippers. That was the existing form of competition, and competition not only was permitted, but it was enjoined by law, and any attempt to restrain it was, as it now is, unlawful. It was by giving special rates that railroad companies induced people to build factories and packing houses and elevators and a great variety of other business establishments along the lines of their roads; that was the way they built up their business and built up the country through which the roads ran. In recent years, however, the people of the country have come to an appreciation of 


\section{THE CITIZEN'S PART IN GOVERNMENT}

the idea that these great public agencies, which have conferred upon them the right of eminent domain and perpetual franchises to enable them to do public service, cannot give special rates to some men without doing injustice to other men; and that the common right of the people demands equality of facility and of cost in the transportation which the railroads are bound to furnish, and condemns special privileges to one as against another. The lesson of all this is that the prosecutions and convictions for violation of the anti-rebate law-things which were never heard of thirty years ago-are not evidence that we are growing worse, but evidence that we are growing better; that our Government is applying a higher standard of justice in the control of public utilities.

The same is true of the management of corporations and the manipulation of securities, to which attention has recently been called sharply by the testimony before the Interstate Commerce Commission regarding the reorganization of the Chicago and Alton Railroad. Thirty or forty years ago, when the management of the Erie Railroad and the Atlantic and Great Western and the Union Pacific Railroad attracted public attention, 
the things done by corporate managers were so much worse that the Chicago and Alton affair would not have received any notice at all. The railroad wrecker was a common type of railroad manager. A large part of our people assumed that to be a permissible game to play, and the rules of the game did not go much beyond the exclusion of ordinary forgery, larceny, and fraud at common law. Since then a higher standard is asserting itself, which recognizes the scrupulous obligation of trusteeship on the part of the railroad manager and promoter, and under that standard much is properly condemned which before would have passed without notice. It is perfectly safe to assert that the standard of probity and fidelity among the corporation managers of the country is higher now than it ever has been before; and yet there is more complaint now than there ever has been before, because our people demand that a more rigid rule of morality shall be applied by statute and by the courts and in administrative supervision than they formerly considered necessary.

The prosecutions which the Departments of the Interior and of Justice have been conducting 


\section{THE CITIZEN'S PART IN GOVERNMENT}

against the land thieves in the West-the men who have been appropriating to themselves the public timber lands and grazing lands and coal lands-have awakened intense indignation among the defendants and their friends, because the wrong was so inveterate that they had come to look upon it as a right. For more than a generation it had been regarded as a natural and unobjectionable thing to get possession of the public land by hook or by crook; and when the officers of the law presented and enforced the novel idea that it was as dishonest to deprive the Government of its land illegally as to deprive an individual of his land illegally, it seemed a cruel injustice. There was simply a little advance of the moral standard which gave life to laws that had been dead before. The whole system of the Federal Government has been lifted up to a higher plane of clearer moral vision, just as the whole system of British administration has been lifted up since the corrupt days of Walpole.

The elective franchise has become a more honest expression of popular will. Only men who are now growing old can remember, and history has not yet adequately recorded, the gross frauds, the 
tricks and devices, and acts of violence which prevented fair elections forty-odd years ago, before the Federal election laws of 1870 and 1871-laws which have passed out of existence, but have left their impress upon the legislation of the States of the Union. In those days, before there was any registration of voters, the wayfaring man could vote the resident out of house and home, and the count of votes was at the mercy of anybody who could succeed in buying a local election officer. The ballots with which to vote were furnished only by the local party organization, and were printed and folded and bunched and distributed by the workers of each party. I have known the voters of a Congressional district to go to the polls on election day and find all the Congressional ballots distributed for one candidate, and none to be obtained for the other candidate, because the local leader on one side had been bought by the other side. I have seen a file of men marched out of a tramp lodging-house with their ballots held aloft in one hand continuously in plain sight until they had deposited them in the ballot box, in order to give the necessary evidence that they were voting according to the contract under which they were 


\section{THE CITIZEN'S PART IN GOVERNMENT}

immediately thereafter to be paid. Now, the system of registration and the revision of the registry lists are substantially effective to confine voting to the qualified voters. The ballot is furnished by the State; the method of voting upon the Australian ballot in all its forms, by marking it in secret, makes bribery uncertain and unprofitable, because it is impossible to tell how any one votes, and the man who would take money for his vote cannot be depended upon to vote as he has agreed. Both the voting and the counting are protected by adequate supervision and full opportunity for watchers in the interest of the candidates and of the different parties. The change from dishonest and unfair elections to honest and fair elections is fundamental to the successful working of popular government and is in the course of ordinary and natural political development. It is the same kind of change which has taken place in England since the days before the Reform Bill of 1832; and that it is permanently effective we may be sure, because it is the natural course of political development here, as it has been in England.

I need not describe the growth, the maintenance, the systematic regulation, and efficiency of public 
and private charities, of public and private institutions for education, for the diffusion of knowledge, for the prosecution of scientific research and experiment, and for the encouragement of art-the enormous sums of money applied to these purposes, the active and unwearying efforts of multitudes of men and women devoted to them; for these are a part of the daily life of every American community. They show an advance in public intelligence and moral qualities working through that associated effort which is essential to government, and to which government is essential; and they justify the expectation of continued advancement in the future.

The fact that American popular government now has serious and difficult questions to deal with is no just cause for distrust. Government always has difficult questions to deal with, and we are assured by the advance already made of democracy's competency in the future. The great questions of capital and labor, of concentrated corporate wealth, and of diffused and general well-being, are merely natural incidents to progress.

The inventions and discoveries of the last century, the applications of science to useful arts, 


\section{THE CITIZEN'S PART IN GOVERNMENT}

have enormously increased the productive power and therefore the wealth of mankind. By the use of machinery and newly devised processes the same number of men can produce, in manufacture and in agriculture, a far greater quantity and variety of the objects which contribute to the necessities, the comfort, and the pleasures of man than in former years. Unsuspected riches of the earth have been revealed and appropriated. Facilities for transportation have given a value to products which would once have been worthless because not needed at the point of production and not available for use elsewhere.

We are now witnessing the natural and inevitable struggle for a fair division of this new and rapidly increasing wealth. The ideal distribution would be that the inventor and discoverer, the organizing and directing intelligence and energy, should have a fair share for their contribution; that the capitalist should have a fair share for the use of his money and the risk which he incurs, measured by the chances of loss which so frequently turn against him; that the wageworker should have his fair share in increase of wages and decrease in hours of labor, because he produces 
so much more by his labor than he formerly did; and that the consumers should have their fair share in decrease of price of the objects which are produced with so much less expense and effort.

It is inevitable that each one of these classes should differ from all the others as to the share to which it is entitled, and that there should be a continual struggle between them in the process of adjustment leading to a fair division. That process and that struggle will continue so long as wealth continues to increase.

One inevitable incident of this process is that at the outset some of these classes will get more than their share, and these are usually the organizer and the capitalist, because they have the advantage of initial position in respect of each new increment of wealth; so that the struggle ordinarily takes the form of demands by the wageworkers and the consumers to increase their shares of the new wealth at the expense of the capitalists and the organizers. Another incident of the process is that the laws framed to meet one set of conditions are constantly being found to need modification in order to insure just distribution of wealth and just rewards 


\section{THE CITIZEN'S PART IN GOVERNMENT}

of intelligence, skill, and industry under the new conditions brought about by industrial progress. We are constantly finding that laws formerly adequate, when applied to new conditions permit some men to get lawfully more than is fair, while others cannot get lawfully as much as their fair share out of the industrial activity to which the whole community contributes in varying ways and degrees. For example, the laws relating to corporate organization, capitalization, consolidation, reorganization, and extension, which formerly served their purpose very well, are now seen to make it possible for some men who get into corporate control to make enormous fortunes without apparently violating any law, but for which they render really no return whatever to the wealth of the community. Morally, the action of these men does not necessarily differ in kind from the action which always has prevailed in the business world, where men determine the price of their commodities rather by what they will bring in the market than by any estimate of the good they will do the purchasers. But these great transactions call attention sharply to the fact that the legal rules governing corporate business require to be changed 
so that unconscionable advantages cannot be lawfully obtained; and moreover such transactions are often accompanied by such suppressions of full information and disregard of fiduciary obligations as to show that the law needs to be strengthened in those directions.

The facilities of transportation and communication which enable modern business to spread over a great expanse of territory have made it possible for so-called trusts and combinations to be made for the purpose of driving out competitors, restricting production, and increasing prices, for which the old and simple rules designed to prevent engrossing, forestalling, and regrating in the English rural community are quite inadequate; and new laws and new agencies for their enforcement are necessary to accomplish the same results.

On the other hand, labor organizations, designed for the just purpose of securing fair treatment as to employment, wages, and hours and conditions of work, are on their part endeavoring to put up prices, restrict production, and drive out competition by stringent rules which prohibit any member from doing more than a specified amount of work each day under penalty of expulsion, and which 


\section{THE CITIZEN'S PART IN GOVERNMENT}

prohibit the employment of any one not a member of the union under penalty of a strike.

All of these things are but incidents of the process of adjustment in the division of the new wealth; some of them come from attempts to get what is fair and some of them from attempts to get more than is fair. Our popular government is dealing with them assiduously, by awakened public opinion gradually crystallizing into laws adapted to meet the new conditions. This process involves no new principles, but merely the adaptation of the same old principles of law with which our fathers were familiar. The things which are happening and the necessity for continual reform of law and administration argue no decline in business morality and no inadequacy of our political system to continue its efficacy and its improvement.

There is occasionally undue excitement; but it is temporary, and whenever it is seen to approach the verge of destructive action it is promptly calmed and restrained by the sober judgment of the people.

Some workingmen's associations hold meetings where violent speeches are made and carry red flags in processions; but so far, whenever a square issue 
is raised among any great and widespread body of laboring men between anarchy and socialism on one side and the principles which underlie the American social and industrial system on the other, the decision is in favor of good Americanism. The Secretary of Commerce and Labor informs me that within the last dozen years the percentage of socialists in the labor organizations of the United States has decreased from about thirty-three per cent to about eight per cent. I do not know to what extent this has been by change within the labor organizations, or to what extent by separation of socialists from the organizations. However it has come about it indicates that so far the sober judgment of the great mass of the wageworkers of the United States is in favor of the conditions of their present prosperity as against socialism.

In considering the efficiency of democratic institutions we must remember the millions of immigrants who have come to us. Americans acquired habits of self-control and political capacity from several centuries of self-government in the American colonies and in the United States down to the middle of the nineteenth century, and from many 


\section{THE CITIZEN'S PART IN GOVERNMENT}

centuries of political growth in England before the colonization of America. The vast mass of our immigrants, however, have come from countries in which there was but little political training or development among the people. Since 1850 over twenty-one million immigrants have entered the United States. Most of these have come with the inherited tendencies, the traditions, and the acquired habits of hopeless submission to a superior external power, or of violent struggle against it, and with little, if any, preparation either of habit or understanding, for the performance of duties of government themselves; and they have had to be educated in mind and in character for selfgovernment.

By far the greater number of the violent and extreme agitators among the laboring men in the United States are the comparatively newly arrived immigrants, whose habits of thought and emotional attitude have been acquired in their former homes. I believe it to be true that, making due allowance for some individuals of the crank variety, and for some individuals who are really ordinary criminals with the shrewdness to carry on their war against society under color of philosophical theories, the tendency of the newcomer 
to violent socialistic or anarchistic denunciation is in inverse proportion to the amount of liberty he enjoyed before he came to this country; that it decreases in direct proportion to the length of time that he lives here and the extent to which he mingles with and becomes a part of the community; and that it tends strongly to disappear with the second generation which has had the opportunity to take in the impressions and influences of American life and education during the impressionable years of childhood. Few things in history are more impressive and extraordinary than the force and effect of American life and institutions upon all these millions of people who have come from all parts of the earth, sprung from all races, speaking all languages, believing in all religions, and bringing with them all kinds of inherited characteristics and tendencies.

Underlying our just hopes for the future effciency and progress of our institutions lie the sound and wholesome character of our people as shown in their daily life; the widely diffused interest in the prosperity of the country shown in the comfort of living and the opportunities for advancement among the people of all callings down to the humblest; the widespread interest to main- 
tain the rights of property, among the owners of the farms, which according to the last census numbered 5,739,657, and among the savings-bank depositors, who in the year 1906 numbered 8,027,192 , having an aggregate deposit of $\$ 3,482,137$,198; the continual process of education under which during the school year ending June, 1906, there were instructed in the schools of the United States $18,434,847$ scholars; the vast influence proceeding from our institutions of higher education -the universities and colleges and professional and technological schools-in which during the past year there were 210,333 students; and the freedom of religion under which all churches, separate from the state, prosper according to the measure in which they meet the religious needs of voluntary worship. More than all, our hopes must depend upon the general and active participation of the whole governing body of the American democracy in working out the problems and applying the principles of government with wisdom, with integrity, with just and kindly consideration for the rights of others-every citizen doing his full and manly duty for his country. The country's future, with its blessings or its 
misfortunes, with its happiness or its misery, its progress or its decadence, depends upon all of us, and it depends upon each one of us.

I commend to you as a guide to your duty of citizenship these words of Lecky, the historian -not a rhetorician, but a discriminating and thoughtful student:

All civic virtue, all the heroism and self-sacrifice of patriotism spring ultimately from the habit men acquire of regarding their nation as a great organic whole, identifying themselves with its fortunes in the past as in the present, and looking forward anxiously to its future destinies. When the members of any nation have come to regard their country as nothing more than the plot of ground on which they reside, and their government as a mere organization for providing police or contracting treaties; when they have ceased to entertain any warmer feelings for one another than those which private interest, or personal friendship, or a mere general philanthropy, may produce, the moral dissolution of that nation is at hand. Even in the order of material interests the well-being of each generation is in a great degree dependent upon the forbearance, self-sacrifice, and providence of those who have preceded it, and civic virtues can never flourish in a generation which thinks only of itself. 
PRINTED IN THE UNITED States OF AMERICA 


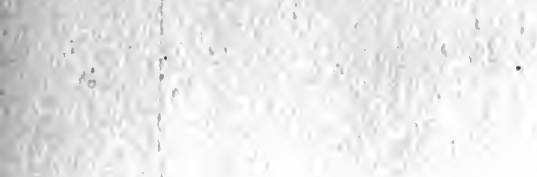$$
\text { (i․ }
$$ 



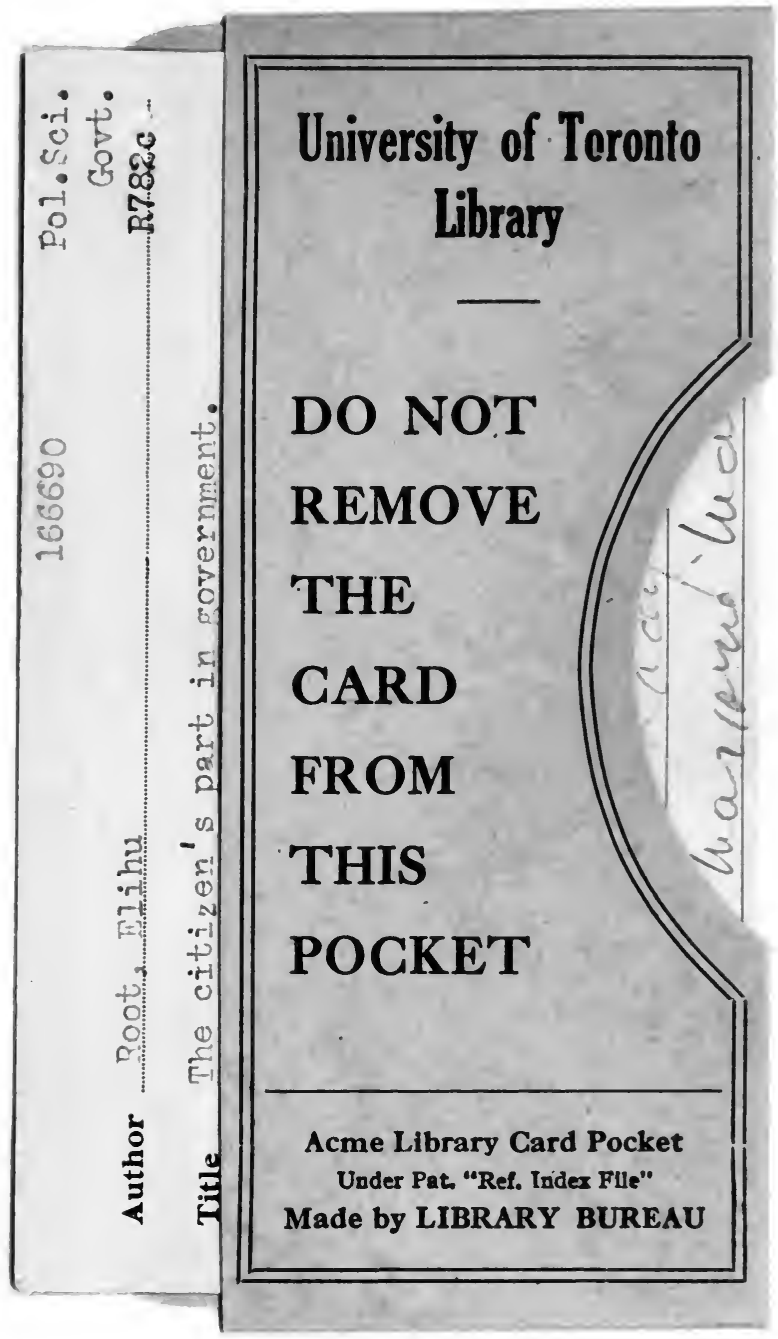


